\title{
Wine polyphenols and promotion of cardiac health
}

\author{
Karen A. Cooper ${ }^{1}$, Mridula Chopra ${ }^{2}$ and David I. Thurnham*1 \\ ${ }^{1}$ Northern Ireland Centre for Food and Health, University of Ulster, Coleraine, \\ County Londonderry BT55 1SA, UK \\ ${ }^{2}$ School of Pharmacy and Biomedical Sciences, IBBS, University of Portsmouth, \\ Portsmouth PO1 2DT, UK
}

\begin{abstract}
Wine polyphenols are considered to have beneficial effects on CHD and atherosclerosis. The consumption of red wine is high in Italy and France, approximately four times greater than that in the UK. This disparity in red wine consumption is thought to be the reason for the 'French paradox', where France was shown to have a coronary mortality rate close to that of China or Japan despite saturated fat intakes and cholesterol levels similar to the UK and USA. In the present review, we discuss the effects of wine and some of its polyphenol constituents on early pathological indicators of CHD such as plasma lipids, the endothelium and vasculature, platelets and serum antioxidant activity. The review also examines whether the polyphenols or the alcohol in wine is responsible for the effects on markers of heart disease. The present review concludes that red wine polyphenols have little effect on plasma lipid concentrations but wine consumption appears to reduce the susceptibility of LDL to oxidation and increase serum antioxidant capacity. However, these effects do depend on the amount of wine and period of supplementation. Authors who have examined specific polyphenols suggest that some phenolics appear to have endothelium-dependent vaso-relaxing abilities and some a positive effect on NO concentrations. Red wine phenolics also have an inhibitory effect on platelet aggregation, and individual phenolics also have a similar effect in vitro, although it should be noted that there are often discrepancies as large as ten-fold between the concentrations of polyphenolics tested in vitro and their measured levels in vivo. Evidence suggests that alcohol has a positive synergistic effect with wine polyphenols on some atherosclerotic risk factors. Thus evidence that wine drinking is beneficial for cardiac health continues to accumulate but more research is required to understand fully and exactly the functions of red wine polyphenols.
\end{abstract}

Wine polyphenols: Coronary heart disease: Alcohol: Antioxidants

\section{Introduction}

'Wine is a biochemical challenge. It is a daunting task to probe the alchemy of this elixir and to determine what lies 'at the heart of the matter'.'

(Goldberg et al. 1995a)

Wine has been a part of human culture for 6000 years, with the first documented vineyard being planted by Noah after the Great Flood (Jackson, 1994; Soleas et al. 1997a). Since that time, wine consumption has been recorded in various countries as a part of their rich culture and diet with the Mediterranean areas appearing to enjoy better health as a consequence of their indulgence (Kushi et al. 1995; Trichopoulou et al. 1995; Willett et al. 1995). The Mediterranean diet is characterised by high intakes of fruit, fish, cooked vegetables, salad, wines and the use of olive oil (Tjønneland et al. 1999) and has long been considered one of the healthier European diets (Nestle, 1995; Trichopoulou et al. 1995).

In 1997, Luxembourg was recorded as having the highest annual wine consumption per capita in the world at 63.3 litres (The Wine Institute, 1999) (Table 1). Wine consumption in France and Italy was only slightly lower than in Luxembourg although it has fallen almost by half since 1970. Annual consumption levels in the UK were 14 litres per capita while in the USA and Canada, the levels were only half that and Oriental countries tend to have the lowest consumption. In Denmark and Australia more wine is drunk than in the UK and consumption has increased threeto five-fold since 1970 . In the UK there was a very low wine consumption in $1970(2 \cdot 2$ litres per capita) but in 1980 it apparently rose steeply to 30 litres and fell to 14 litres by 1997. However these amounts pale in significance

\footnotetext{
Abbreviations: CETP, cholesteryl ester transfer protein; oxLDL, oxidised LDL.

* Corresponding author: Professor David I. Thurnham, fax +44 2870 324965, email di.thurnham@ulster.ac.uk
} 
Table 1. Per capita wine consumption by country over the past three decades

\begin{tabular}{lccc}
\hline Country & \multicolumn{3}{c}{ Per capita annual wine consumption (litres) } \\
\cline { 2 - 4 } & 1997 & 1980 & 1970 \\
\hline Luxembourg & 63.30 & $/$ & $/$ \\
France & 60.13 & 90.87 & 108.22 \\
Italy & 58.05 & 79.87 & 110.83 \\
Spain & 36.87 & 59.91 & 61.43 \\
Denmark & 29.14 & 12.78 & 5.90 \\
Australia & 18.95 & 17.38 & 8.50 \\
UK & 13.99 & 30.13 & 2.87 \\
Chile & 13.57 & 50.24 & 43.85 \\
South Africa & 8.92 & 9.07 & 11.19 \\
Canada & 7.39 & 8.35 & 2.19 \\
USA & 7.38 & 7.98 & 4.95 \\
Ireland & 5.32 & 3.21 & 3.29 \\
Japan & 1.69 & 0.38 & 0.30 \\
China & 0.36 & $/$ & $/$ \\
Egypt & 0.05 & $/$ & $/$ \\
\hline
\end{tabular}

${ }^{*}$ The Wine Institute (1999).

in comparison with the volumes consumed in the top three countries of the world, i.e. Luxembourg, France and Italy. Furthermore, despite the known associations between excessive alcohol consumption and mortality from liver diseases (Singh \& Hoyert, 2000), there is a general trend for lower mortality from IHD in countries with a higher wine consumption per capita (Figs. 1 (a) and (b)). However, there are exceptions and in other countries with extremely low IHD mortality rates, such as Japan and China, wine consumption is unlikely to be exerting any benefits.

The beneficial properties that wine specifically contributes to the diet are far from clear. Furthermore, different wines have different compositions and therefore benefits may be due to different components. Wines vary depending on the grape cultivar used, the winemaking procedure and conditions of storage. The development of new technology has facilitated the identification of many of the compounds in wine that were previously unknown. At the moment, over 500 different compounds have been documented in different types of wines including water $(74-87 \%, w / w)$, sugars $(0 \cdot 05-10 \%)$, ethanol $(10-14 \%)$, acids $(0 \cdot 05-0 \cdot 7 \%)$, and phenols (0.01-0.2 \%) (Soleas et al. 1997a). Polyphenols have long been considered to be the ingredients in wine that may be beneficial for health because of their antioxidant properties. Hence much research has been directed into this area with several reviews on wine reporting its potential cardioprotective benefits (Cook \& Samman, 1996; Chung et al. 1998; Cao \& Prior, 2000; Estruch, 2000).

The present paper will review the epidemiology of wine consumption and CHD, polyphenols and their structurefunction relationships, the pathology of $\mathrm{CHD}$ and the
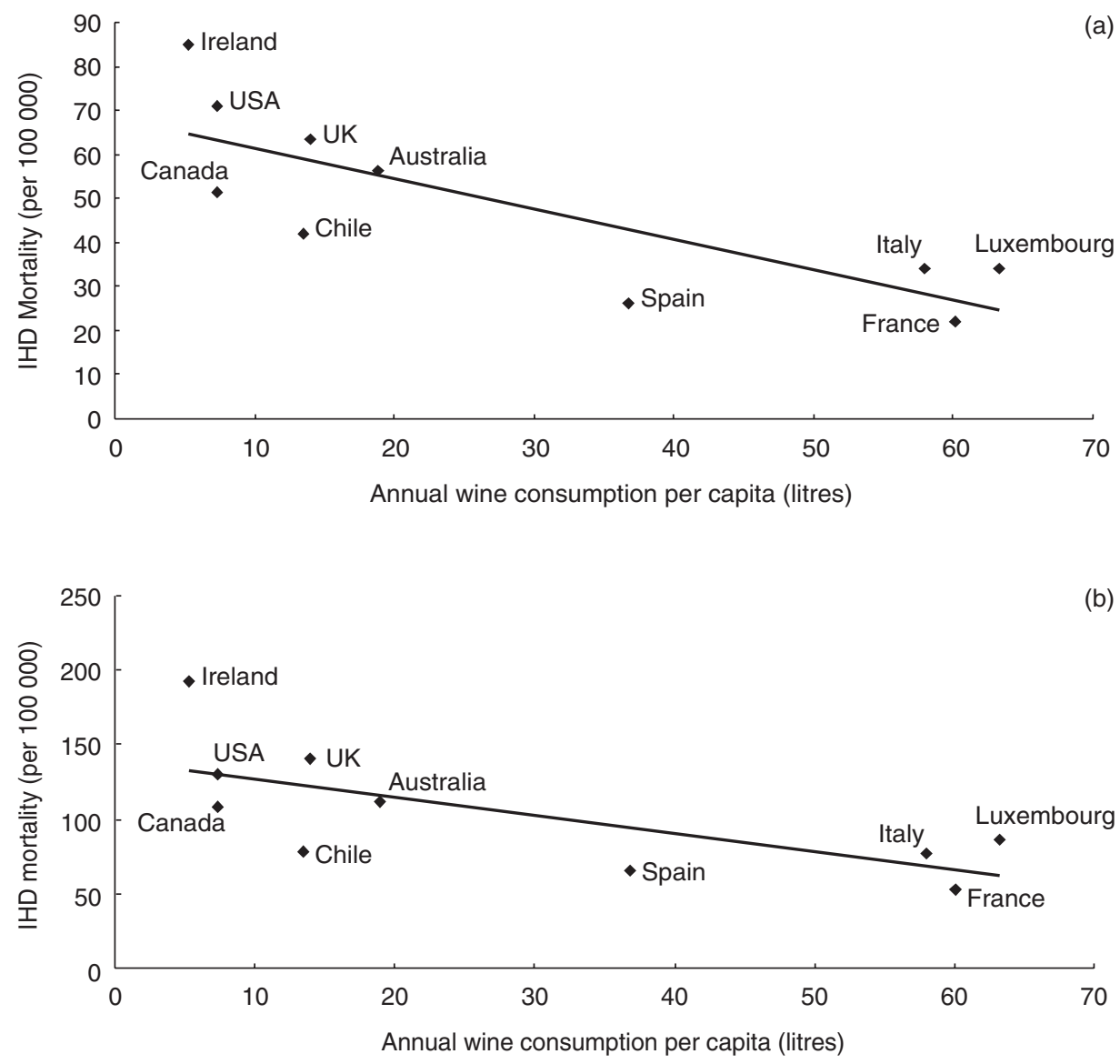

Fig. 1. IHD mortality and wine consumption in the 1990s by country in females (a) (r 0.6469) and males (b) ( $r$ 0.4877), not including Japan, Egypt or China. 
effects of wine and its polyphenols on different aspects of the disease. The overall aim is to describe some of the more recent studies and examine possible mechanisms involved to indicate the direction of current research in this area.

\section{Epidemiology of wine intake and coronary heart disease}

The 'French paradox' was the term that became better known after an unexpected finding of the Monitoring Trends in Cardiovascular Diseases (MONICA) Project (World Health Organization, 1989) and further investigated by Renaud \& de Lorgeril (1992). France was shown to have a coronary mortality rate close to that of China or Japan despite saturated fat intakes and plasma cholesterol concentrations similar to the UK and USA. Wine consumption was suggested as a possible protective factor and a significant inverse correlation was found between the country's wine consumption and mortality from CHD (Renaud \& de Lorgeril, 1992). However, the time-lag hypothesis cast doubt on this explanation of the French paradox (Law \& Wald, 1999). The new hypothesis observed that high animal fat consumption and serum cholesterol levels have only been similar between France and Britain since the mid 1980s. Before this time, the levels of animal fat consumption (about $21 \%$ of total energy consumption in France $v$. about $31 \%$ in Britain) and mean serum cholesterol $(5.7$ v. $6.3 \mathrm{mmol} / \mathrm{l})$ in men aged $50-70$ years were lower in France than the UK (World Health Organization, 1989; Crique \& Ringel, 1994). Therefore Law \& Wald (1999) have suggested that changes will occur in the pattern of CHD in France with increases in atheroma and deaths from CHD within the next 25 to 35 years. However, the criticisms have not been widely accepted and although it may indeed be a factor influencing the pattern of world CHD, human intervention studies with wine polyphenols have indicated effects that should be investigated further.

There is also the possibility that other aspects of diet and lifestyle in France and other Mediterranean countries may be the more important determinants of CHD risk. In a Danish study (Tjønneland et al. 1999), wine drinking in comparison with other alcoholic drinks was associated with a more healthy diet; for example, higher intakes of fruit, fish, cooked vegetables, salad, and the use of olive oil for cooking. However, a similar study in Italy that compared the diets of wine drinkers, mixed drinkers and abstainers found no such correlation between wine drinking and consumption of other 'healthy' foods (Chatenoud et al. 2000). It should be noted, however, that the consumption of wine in Italy and Denmark is not comparable. Italians consume approximately twice as much per capita as Danes (Table 1) and IHD mortality is almost 3.5 times higher in Denmark than in Italy (Figs. 1 (a) and (b)). Recently, Di Bari et al. (2003) conducted a study on an elderly Italian population in whom the mean daily consumption of wine was $176 \mathrm{ml}$ (equivalent to 64 litres annually and comparable with the 1997 values in Table 1 of 60 litres annually). It was found that the daily wine intake was significantly inversely associated with a marker of CHD, namely antibodies for oxidised LDL (oxLDL) (Di Bari et al. 2003). Therefore evidence continues to appear suggesting that wine con- sumption is a separate dietary factor protecting against heart disease.

One question, which is still not answered, is whether the apparent cardioprotective effects associated with wine consumption stem from the alcohol, other wine components or a mixture of the two. Alcohol intake in general is inversely correlated to the risk of CHD but the link with wine alcohol specifically is stronger than beer alcohol and more consistent (Crique \& Ringel, 1994). In an early paper by St Leger et al. (1979), a strong negative correlation between IHD mortality and alcohol consumption was reported. However, after categorising the alcohol consumption into wines, beers and spirits, it appeared that wine was the most strongly associated with the cardioprotective effect. Such effects may be due to trace compounds present in wine but the authors precluded further work to isolate these constituents by suggesting it was 'almost a sacrilege, as the medicine is already in a highly palatable form'! However, as some societies do not consume alcohol for cultural reasons, further research to isolate and identify the factors responsible for the beneficial effects of wine is needed. A meta-analysis in 1996 of ecological, case-control and cohort studies comparing wine, beer and spirits and their associations with CHD risk found that there was strong evidence to suggest that all alcoholic drinks in moderation were linked to lower risk. The authors suggested that any stronger association of wine with a lower CHD risk was probably due to patterns of drinking and lifestyle factors that were not fully controlled for in other studies (Rimm et al. 1996), although if there were not enough wine drinkers in the country, this may explain why a stronger association was not made. Drinking patterns such as wine drinking with meals, or daily $v$. weekend binge drinking are important aspects to be documented when reporting epidemiological links between alcohol consumption and CHD risk. For example, it has been found that coronary event risk is lowest among men who report one to four drinks (and women one to two drinks) daily on 5 or $6 \mathrm{~d}$ of the week (McElduff \& Dobson, 1997). It should be noted that alcoholic patterns of drinking habits are continually on the change; for example, France has a beer industry worth $£ 5$ billion that is on the increase, whilst the wine industry at $£ 8$ billion is shrinking (UK Trade and Investment, 2004).

\section{Polyphenols in wine}

\section{Structure and classification}

Polyphenols can be split into two groups; flavonoids and non-flavonoids. Flavonoids are the most common and widely distributed group of phenolics (Bravo, 1998). Fig. 2 shows the basic structure of flavonoids, which comprise two phenol moieties connected via a pyran ring and possessing several hydroxyl and/or ketone groups. They can exist in the free form (i.e. aglycone), polymerised, linked to a sugar moiety (i.e. glycoside) or linked to other nonflavonoid phenols (Ursini et al. 1999). The most common sugar residue is glucose but others such as galactose, rhamnose, xylose and arabinose are found (Bravo, 1998). Over 4000 individual flavonoid compounds are known to occur in nature (Harbourne, 1994). The structure of flavonoids 


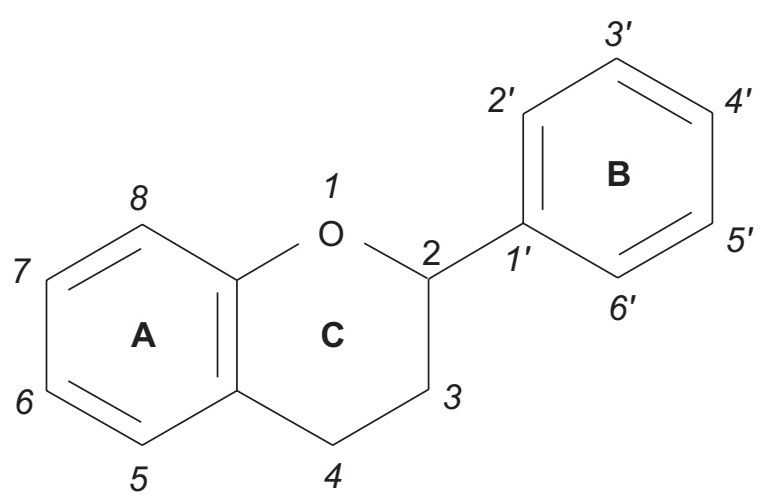

Fig. 2. The general structure of flavonoids. The three phenolic (pyrane) rings are referred to as $A, B$ and $C$ and the numbering systems are used to allow easier identification of the position of substitutions in the rings.

allows many patterns of substitution into the benzene rings to create the wide variety of compounds found in nature (Hollman, 1997). Most flavonoids are soluble in aqueous media but the degree of solubility depends on their polarity and chemical structure (Bravo, 1998). Extensive information on flavonoids and advances in research has been reviewed by Middleton \& Kandaswami (1995).

Flavonoids can be classified by the oxidation level of their central C-ring, i.e. by the number and position of hydroxyl groups. The flavonoid classes include anthocyanidins, flavones, flavonols, flavandiols (leucoanthocyanidins), aurones, biflavonoids, chalcones, dihydrochalcones, flavanones, dihydroflavonols, flavans and isoflavonoids (Bravo, 1998). In addition, there are polymeric compounds called tannins (Cook \& Samman, 1996). These classes can further be subdivided by the number and type of substituents present.

\section{Flavonols, flavanols and flavones}

The flavonol class is an important group of compounds in the diet and includes such examples as quercetin, myricetin (Fig. 3), kaempferol and isorhamnetin. Flavonols are found in a wide variety of foods, e.g. leeks, broccoli, onion, lettuce, cranberries, apples, olives and beverages such as tea and red wine. Red wine contains approximately 4-16 mg quercetin/l and 7-9 mg myricetin/l (Hertog et al. 1993). Flavones differ from flavonols by a lack of hydroxylation on the $\mathrm{C}_{3}$ on the C-ring (Fig. 2) (Harbourne, 2000). The most abundant flavones are luteolin and apigenin. Flavonoids and other similar types such as catechins are generally bound to sugars to increase their solubility. The flavanol group consists of optically active isomers such as (+)-catechin, (-)-epicatechin (Fig. 3) and their gallates. The flavanols are also known as the catechins or flavan-3ols. Flavanols have a feature that is only shared by anthocyanidins, namely they lack the ketone group at the 4-position of the heterocyclic C-ring (Hollman \& Arts, 2000). Flavanols are popularly associated with tea, rather than wine, but there are higher concentrations of catechins in red wine than all the other flavonoid compounds (Goldberg et al. 1998). A detailed review on flavonols, flavones and flavanols has been published recently that covers the nature, occurrence and dietary amounts of these compounds (Hollman \& Arts, 2000).

\section{Tannins}

Tannins are polymeric structures comprising from a few to over 100 flavonoid units giving a high molecular weight (Santos-Buelga \& Scalbert, 2000). Tannins can form insoluble complexes with carbohydrates and proteins such as the salivary proteins in vivo (Bravo, 1998). Some tannins are hydrolysable, meaning that gallic acid or a similar compound is present, bonded to a carbohydrate (for example, tannic acid). Other tannins can be formed by the polymerisation of flavonoids through condensation reactions, for example, proanthocyanidins (Cook \& Samman, 1996). Proanthocyanidins are so called because they yield one or more anthocyanidins in the presence of strong acids. Specific proanthocyanidins give distinct anthocyanidins; for example, procyanidins give cyanidin on hydrolysis and prodelphinidins give delphinidin.

Proanthocyanidins possess a polymerised flavan-3-ol structure with basic units of catechin (dihydroxylated in the B-ring) or gallocatechin (trihydroxylated in the B-ring) (de Pascual-Teresa et al. 2000). Red wine can have a great range of proanthocyanidin concentrations, for example, 1-200 mg type B1/1 (a dimer of epicatechin and catechin) (Santos-Buelga \& Scalbert, 2000). Proanthocyanidins can act as antioxidants by complexing with metallic ions or radical scavengers (Virgili et al. 1998; Plumb et al. 2000; Santos-Buelga \& Scalbert, 2000). Other properties include providing astringency in food, possibly protecting against some human diseases, for example, CHD and cancer (Bravo, 1998), interacting with anthocyanins to affect the colour of red wine (Francia-Aricha et al. 1997; Saucier et al. 1997) and complexing with metal ions to inhibit nonhaem $\mathrm{Fe}$ absorption. It is suggested that proanthocyanidins can aid the prevention of cardiovascular disease by protecting LDL against oxidation and inhibiting platelet aggregation (Santos-Buelga \& Scalbert, 2000). The anthocyanins are important pigments with over 300 occurring in nature and the water-soluble and acyl-glycosidic forms of anthocyanidins are now widely used in the food industry as food colourants (Harbourne, 1994).

\section{Resveratrol}

Resveratrol (Fig. 3) is a molecule (3,5,4'-trihydroxystilbene) that has been the subject of much speculation and is renowned for its possibly beneficial effects on atherosclerosis and cancer (Jeandet et al. 1993). Resveratrol and piceid (3 $\beta$-glucoside of resveratrol) are both sensitive to light and air oxidation, which makes their extraction from grapes and wines difficult (Pezet et al. 1994). It can be found in grape products where it is primarily sourced from the skin of the grape but virtually absent in the flesh (Lamuela-Raventós \& Waterhouse, 1999); however, it has been found at relatively high concentrations in seeds of the Muscadine grape (Ector et al. 1996). Resveratrol is a phytoalexin, which is part of the natural plant defence system against fungal infection (Soleas et al. 1995) and is reported to be an indicator of 
<smiles>O=c1c(O)c(-c2ccc(O)c(O)c2)oc2cc(O)cc(O)c12</smiles>

Flavonols

Flavan-3-ols (catechins)<smiles>Oc1cc(O)c2c(c1)OC(c1ccc(O)c(O)c1)C(O)C2</smiles><smiles>Oc1cc(O)c2c(c1)OC(c1ccc(O)c(O)c1)C(O)C2</smiles><smiles>OC1=C(c2ccc(O)c(O)c2)Oc2cc(O)cc(O)c2C1</smiles>

Anthocyanidins<smiles>O=c1c(O)c(-c2cc(O)c(O)c(O)c2)oc2cc(O)cc(O)c12</smiles> 
disease resistance in different vine varieties (Pezet et al. 1994). However, it has been found that extensive infection before harvest can lower the resveratrol content of the resultant wine by rapidly spreading lesions from which laccase, an enzyme from the Botrytis pathogen, is released and degrades the resveratrol (Jeandet et al. 1995). Burgundy Pinot Noir red wines have been found to contain relatively high concentrations of resveratrol from 1.6 to $8.7 \mu \mathrm{mol} / \mathrm{l}$, compared with white Chardonnay wines that contained only 0.004 to $0.4 \mu \mathrm{mol} / 1$ (Jeandet et al. 1993). Another study also found consistently high resveratrol levels in Pinot Noir wines (Goldberg et al. 1995b). Varying concentrations have been measured in Swiss (Pezet et al. 1994), Californian (Lamuela-Raventos \& Waterhouse, 1993) and Japanese (Okuda \& Yokotsuka, 1996) wines of different grape types. Recently the occurrence of a resveratrol dihydrodimer at a concentration range of 0.44 to $1.32 \mu \mathrm{mol} / 1$ was reported for red and rosé wines (Adrian et al. 2000). Ingestion of resveratrol and its derivatives may be as high as $3 \cdot 1$ to $12 \cdot 3 \mu \mathrm{mol} / \mathrm{d}$ for moderate consumers of Spanish red wines (200 ml/d) (Lamuela-Raventós et al. 1995). However, this suggests a maximum resveratrol concentration of approximately $60 \mu \mathrm{mol} / \mathrm{l}$, which is much higher than that found in most of the wines tested by LamuelaRaventós et al. (1995).

\section{Non-flavonoids}

Non-flavonoid components of wine are simple abundant phenols with a variety of different functional groups present. They can be grouped as benzoic-based compounds (for example, vanillic, gallic and protocatechuic acids), benzaldehydes (for example, vanillin, syringealdehyde), cinnamic acids (for example, $p$-coumaric, ferulic, chlorogenic and caffeic acids) and cinnamaldehydes (for example, coniferaldehyde, sinapaldehyde). Wine astringency is attributed to the presence of the larger polyphenols and the smaller phenolic acids account for bitterness. Volatile phenols can contribute towards effects such as smokiness, vanilla character, pungency and bitterness but these components are usually only present in tiny amounts and especially so in young wines (Singleton, 1982). Polyphenols in wine originate mainly from the skin and seeds of the grape but can also be derived from the vine stems, the wood used for barrels and from yeast metabolism (Soleas et al. $1997 a)$.

In summary, there are many different groups of phenolics present in red wine, with flavonols being considered to be the most biologically important. However, flavanols and resveratrol have also received much attention recently. Non-flavonoids appear to not be considered as being important although they are generally present in abundance. The concentrations of total phenolics in commercially available red wines are rarely over $2 \cdot 5 \mathrm{~g} / \mathrm{l}$ as measured by the Folin-Ciocalteau method (Singleton, 1982).

\section{Structure and antioxidant-function relationships}

For a flavonoid to be an effective antioxidant, it requires three characteristics. The first requirement is a hydroxyl group $(-\mathrm{OH})$ on the unsaturated C-ring at position 3 (Fig.
2 ), which confers higher stability of the radical due to delocalisation of electrons. The second requirement is a 2,3double bond in conjugation with the oxo group $(=\mathrm{O})$ at position 4 in the $\mathrm{C}$-ring with the presence of an -OH group at positions 3 and 5 with the oxo function in the A- and Crings increasing the radical-scavenging potential of the compound. Third, to be effective, a flavonoid requires an $o$ dihydroxy structure in the B-ring (Bors et al. 1990). Quercetin is a flavonol that has all three of these characteristics and is one of the most powerful natural antioxidants (Bravo, 1998). If any of these requirements are not met, the antioxidant activity of the molecule is reduced. The number of hydroxyl groups the flavonoid has can determine its radical-scavenging ability; for example, myricetin has six hydroxyl groups and has a greater antioxidant capacity than kaempferol, which has four hydroxyl groups when tested under the same conditions (Husain et al. 1987; Cook \& Samman, 1996). If one of these $-\mathrm{OH}$ groups is at position 3 , then this greatly enhances its antioxidant capacity compared with another flavonoid with the same number of hydroxyl groups. The pattern of hydroxylation is important, mainly positions 3 (C-ring), 5 and 7 (A-ring), and 3' and 4' (B-ring) appear to enhance the inhibition of lipoprotein oxidation (Cook \& Samman, 1996). If the flavonoid is linked to a sugar moiety, it hinders the scavenging ability of the remaining hydroxyl groups. Thus, in vitro, aglycones are reported to show a higher scavenging potency than their comparable glycosides (Cook \& Samman, 1996). A flavonoid with both a ketone group at position 4 and a hydroxyl group at either position 3 or 5 (for example, rutin, quercetin) will have the ability to chelate Fe ions, which prevents the metal ions being used in the Fenton system to generate free radicals. Then, once formed, the flavonoid-Fe complex still has the ability to scavenge free radicals.

Antioxidants are thought to lower the risk of CHD by lowering the concentration of free radicals in the body and so reduce the likelihood that one of the radicals will cause oxidative damage (Parr \& Bolwell, 2000). Vitamin E is one of the most important antioxidants present in the plasma and LDL, and additional dietary antioxidants can either spare vitamin E from oxidation or assist in its regeneration after oxidation. Testing the antioxidant potential of a compound in vitro on plasma or LDL can be performed by either the compound being added at the start of the reaction, i.e. to prevent vitamin $\mathrm{E}$ utilisation, or being added at different time points after initiation, i.e. to assist the regeneration of vitamin E. A flavonoid-rich extract has been shown to prevent LDL oxidation in vitro in a concentrationdependent manner and to delay the consumption of vitamin $\mathrm{E}$, but not to terminate or delay LDL oxidation once the vitamin $\mathrm{E}$ in the LDL was consumed (Viana et al. 1996). Specific flavonoids have also been tested in a similar manner (Zhu et al. 2000). When present at the start of oxidation, the flavonoids quercetin, myricetin, kaempferol and morin exerted dose-dependent protective activity against the depletion of $\alpha$-tocopherol in LDL over the concentration range 1-20 $\mu \mathrm{mol} / 1$. Kaempferol ( $-\mathrm{OH}$ group at position 4') and morin (-OH groups at positions 2' and 4') were less effective at preventing $\alpha$-tocopherol depletion than quercetin ( $-\mathrm{OH}$ groups at positions $3^{\prime}$ and 4') and myricetin $\left(-\mathrm{OH}\right.$ groups at positions $3^{\prime}, 4^{\prime}$ and $\left.5^{\prime}\right)$. When the 
flavonoids were added $5 \mathrm{~min}$ after initiation, significant regeneration of $\alpha$-tocopherol was observed, with activity related to the number and location of hydroxyl groups in the B-ring (Zhu et al. 2000). These experiments show that flavonoids are active, though not all to the same extent, in both protecting and regenerating $\alpha$-tocopherol in vitro.

In vivo studies may not show the same effect as in vitro work. An animal study found that there were multiple effects from supplementing Fe-loaded rats (impaired antioxidant status) with catechin; more specifically an enhanced platelet function was seen with an increase in total antioxidant status and vitamin E sparing (Blache et al. 2002). However, these effects were only seen in animals with impaired antioxidant status and not in control animals, indicating that if the individual has a normal antioxidant status, then supplementation may have no effect. An in vivo study, in which human volunteers were supplemented with either red wine or quercetin to determine if there is an increase in the oxidative resistance of LDL, did not find any changes in plasma or LDL $\alpha$-tocopherol concentrations (Chopra et al. 2000). Where no effect of flavonoids on vitamin E concentrations was observed, it is possible the concentrations of flavonoids were lower in vivo than in studies performed in vitro, or that the flavonoids were metabolised into a form where the active functional groups were blocked (Day et al. 2000). However, it is more probable that no change in $\alpha$-tocopherol was seen as the concentrations were already optimal and were not under oxidation pressure, and therefore not susceptible to alteration. This is especially so in vivo as $\alpha$-tocopherol is believed to be regenerated by vitamin $\mathrm{C}$ and therefore no changes would be expected in $\alpha$-tocopherol concentrations except under extreme or sustained oxidative stress.

One of the ways of comparing the antioxidant properties of different wines is by measuring their total antioxidant activity by one of the standard methods available, for example, Trolox-equivalent antioxidant activity (RiceEvans \& Miller, 1996) or total phenolic acid content (Singleton \& Rossi, 1965). As expected, a relationship exists between Trolox-equivalent antioxidant activity and the phenolic acid content and the ratio of the two measurements is approximately the same over a range of different wines. Likewise, white wine shows a similar relationship between its total phenolic acid content and Trolox-equivalent antioxidant activity as red wine (Rice-Evans \& Miller, 1996). Although it is considered important to characterise the antioxidant power of wine in vitro, it should be stated that the results do not predict the in vivo situation as the relative absorption of active compounds and efficacy of the resulting metabolites are yet to be established. It should be mentioned that the measurement of the antioxidant power of crude wines should be considered informative only as it cannot represent the real activity that could potentially be obtained in vivo due to the deglycosylation that occurs before absorption, changing the phenolic from conjugate to aglycone and therefore its antioxidant activity.

Soleas et al. (1997b) made an interesting observation with regard to the antioxidant capacity of wine and the concentration of certain phenolics. Using a multivariate analysis, they determined the relative contributions of different polyphenolic constituents to the antioxidant capacity of thirty-two different Ontario wines. They found that $96 \%$ of total antioxidant capacity as measured by the Randox assay (Randox Laboratories Ltd, Crumlin, Co. Antrim, UK) could be predicted from the sum of the micromolar concentrations of catechin, $m$-coumaric acid, epicatechin, cis-polydatin, trans-polydatin, quercetin, trans-resveratrol and vanillic acid in the wine (concentrations of individual polyphenol values not given). The remaining polyphenols (caffeic acid, $p$-coumaric acid, ferulic acid, gentisic acid, isoquercitrin, myricetin, cis-resveratrol, gallic acid, syringic acid) did not contribute significantly to the antioxidant protection. Thus knowledge of the concentrations of certain polyphenols in wines can be used to predict total antioxidant capacity.

In summary, the data available suggest that the mechanisms by which polyphenols exert their antioxidant properties in vivo are: (1) reduction of free radical formation; (2) protection of $\alpha$-tocopherol by preferential oxidation; (3) regeneration of oxidised $\alpha$-tocopherol; (4) chelation of metal ions (Cook \& Samman, 1996).

\section{Coronary heart disease pathology}

Wine polyphenols are believed to have beneficial effects on CHD and atherosclerosis. The term CHD is generally used to refer to cardiac disease specifically due to atherosclerosis of the coronary arteries (Mangiapane \& Salter, 1999). Atherosclerosis is characterised by an accumulation of lipids in the intima of the large arteries and can begin in early childhood. Atherogenesis results from a combination of many pathological factors that are all closely linked and interact to form a lesion. These include endothelial dysfunction, platelet activation, lipoprotein retention, lipoprotein oxidation, lipoprotein aggregation, macrophage foam cell formation, inflammation and thrombosis (Aviram, 1996). Plasma lipoproteins are the major transporters of lipid and lipid-soluble antioxidant compounds and vitamins in serum. LDL is the principal carrier of cholesterol in the blood and HDL particles remove excess or unused cholesterol from cells.

Elevated plasma concentrations of LDL are considered as a risk factor for atherosclerosis, and it is now evident that it is a cause of atherosclerosis as well as a consequence of disease. The permeability of the arterial endothelium to oxLDL may be increased by factors such as high blood pressure, genetic factors, infection and smoking and thereby decreasing the amount of oxLDL in the plasma. Erythrocyte membrane fluidity measurements can be used to indirectly assess endothelial cell membrane fluidity. The latter is a measure of membrane cell flexibility (Sharpe et al. 1995) and low flexibility is associated with an increased risk of atherosclerosis. Modification of LDL via oxidation, nitration, glycation or alkylation can also increase the risk of atherosclerosis. Normally, LDL particles are removed from the circulation via native receptors on macrophages, which recognise the apo B part of LDL. Native receptors are down regulated by elevated cellular cholesterol levels. Modified LDL can be removed by several different scavenger receptors and since these receptors are not down regulated by the cellular cholesterol content, entry of LDL particles through these receptors can lead to increased accu- 
mulation in the cells. It should also be noted that at least one of these receptors (CD36; macrophage type B scavenger receptor) is even up regulated by cellular cholesterol in a lipid-driven self-regulated cycle (Han et al. 1999). Free radicals generated by endothelial cells, monocyte-derived macrophages and smooth muscle cells can oxidise LDL (Cook \& Samman, 1996). OxLDL is found in atherosclerotic lesions and oxLDL can be produced by peroxidation of the PUFA of surface phospholipids in the LDL particle (Mangiapane \& Salter, 1999). Serum HDL concentrations are inversely associated with the risk of CHD (Mangiapane \& Salter, 1999) and may also prevent lipid oxidation by aiding the removal of excess cholesterol from cells within the artery wall. Both LDL and HDL are important factors in atherosclerosis and CHD, and monitoring of these lipoproteins is important in studies investigating potential cardioprotective dietary components.

Atherosclerosis is a chronic inflammatory process that involves a complex interplay of circulating cellular and blood elements with the cells of the artery wall (Witztum \& Steinberg, 2001). OxLDL is now well accepted as an important factor in the development of atherosclerotic plaques and inhibition of LDL oxidation is suggested to inhibit atherosclerosis independent of lowering plasma cholesterol levels (Witztum \& Steinberg, 2001). Various proatherogenic effects of oxLDL have been suggested. These include the promotion of cholesterol accumulation in subendothelial space, macrophage and smooth muscle cell proliferation (Martens et al. 1999; Chai et al. 2002), immunogenic effects leading to autoantibody formation (Tsimikas et al. 2001; Witztum \& Steinberg, 2001), and the induction of NO synthase and apoptosis (Cromheeke et al. 1999). Other pro-atherogenic effects of oxLDL that have been suggested are the activation of signal transducers (Maziere et al. 1999) and transcription factors such as NF$\kappa \mathrm{B}$ (Parhami et al. 1993). The latter is reported to colonise in early and advanced atherosclerotic plaques (Brand et al. 1996).

Some of the these mechanisms, i.e. the inhibition of smooth muscle cell proliferation by resveratrol (Liu \& Liu, 2004) and the inhibition of oxLDL cytotoxicity by red wine and quercetin (Carrero et al. 1998), have been shown in in vitro experiments. However, further studies investigating the effect of wine flavonoids on the transcription of NF- $\kappa \mathrm{B}$ are warranted. The latter is important due to its effects on the pro-inflammatory response and apoptosis, both of which play an important role in the development of atherosclerosis.

\section{Effects of wine on risk factors for coronary heart disease}

Lipid content and oxidative modification: in vitro studies. Many in vitro studies use lipoproteins and plasma obtained from healthy individuals to measure oxidation potential and also to test the effect of added antioxidants. Recently, it was shown that whole red wine could inhibit macrophage-mediated oxidation of lipoproteins when exposed in vitro and that white wine (of similar alcohol content) was not as effective (Rifici et al. 1999). It was found that alcohol alone had no effect; thus the effects of red wine did not appear to be wholly due to the alcohol content. However, as the study did not test de-alcoholised red wine, the possibility of synergistic effects between the alcohol and other wine constituents cannot be excluded.

Instead of using whole wine, some workers have used extracts from red wine and tested these in vitro for antioxidant properties. Frankel et al. (1993) were the first to show the beneficial effects of the non-alcoholic components of red wine on the oxidation of human LDL in vitro. They reported that lipid peroxidation of LDL was inhibited by 60 and $98 \%$ in the presence of 3.8 and $10 \mu \mathrm{mol}$ red wine polyphenols/l respectively. Also, polyphenols from a Cabernet Sauvignon wine prevented cholesterol oxide formation in vitro and displayed $\alpha$-tocopherol-sparing activity (Deckert et al. 2002). Red wine polyphenols have also been shown to have a protective effect on erythrocytes in vitro against $\mathrm{H}_{2} \mathrm{O}_{2}$-induced oxidation (Tedesco et al. 2000). A pure Concord red grape extract rather than wine also inhibited lipid peroxidation in vitro (Lanningham-Foster et al. 1995). These experiments have shown that components of both red grapes and wine, other than alcohol, have inhibitory effects on lipid peroxidation in vitro, but at this point in time, no single component has been identified as the active agent.

Polyphenols in red wine can be fractionated into phenolic groups, allowing comparison between groups for effectiveness of inhibition of LDL oxidation in vitro. One group fractionated a concentrated $(\times 10)$ Syrah wine sample $(25 \mu \mathrm{l})$ using HPLC, collecting ten fractions of $3 \mathrm{ml}$ each in methanol (Teissedre et al. 1996). Three fractions, (1) catechin and procyanidins, (2) epicatechin and procyanidin B2, and (3) procyanidin $\mathrm{C} 1$, inhibited $\mathrm{Cu}$-catalysed LDL oxidation in vitro by 71,65 and $61 \%$ respectively. Fractions containing mainly benzoic acids, $p$-hydroxybenzoic acid and cinnamic acids only inhibited $43 \%$ of the LDL oxidation. The inhibitory effects of fractions containing rutin, myricetin, quercetin and the anthocyanins ranged from 31 to $45 \%$. Studies performed with some increasing equimolar concentrations of simple phenolic acids found the order of effectiveness on reducing LDL oxidation was caffeic acid $>$ sinapic acid $>$ ferulic acid (Carbonneau et al. 1997). These experiments indicate that not all components of red wine are equally effective in inhibiting LDL oxidation, and considering that wines have dissimilar compositions, this might indicate why red wine supplementation trials using different red wines show contradictory results (see p. 121).

As each group of phenolic compounds appears to differ in its effectiveness to inhibit LDL oxidation, it may well be that only a few of the polyphenols present in red wine are responsible for the differences between white and red wine on cardiovascular risk factors. Sharpe et al. (1995) made the suggestion that resveratrol may be one of the protective factors in red wine as it tends to be present in much lower concentrations in white wine than red. However, this is also true for the flavonoids and the more complex polyphenols such as anthocyanins. Still, it is thought that resveratrol could potentially help modulate lipoprotein metabolism, eicosanoid synthesis, oxidation and coagulation in mechanisms currently being explored through in vitro cell culture (Goldberg et al. 1995a). This is particularly of interest as resveratrol and piceid (the $\beta$-glucoside of resveratrol) are known to be the primary active components in the Oriental 
folk medicine for atherosclerosis; 'Kojo-kon' or 'ItadoriKon' made with the roots of Polygonum cuspidatum (Lamuela-Raventós \& Waterhouse, 1999). Thus, in vitro studies are useful indicators of the ranges of effectiveness of the different components in red wine. They indicate which components have the greatest potential as cardioprotective substances and therefore should be further investigated with in vivo human studies.

Lipid content and oxidative modification: in vivo animal studies. Klurfeld \& Kritchevsky (1981) were the first to show the protective effects of red wine using animal studies, with the lowering of the incidence of atherosclerotic lesions. Rabbits were fed diets that approximated that of the US energy consumption with added cholesterol to induce atherosclerosis within a short period and provided red wine, white wine, bourbon whisky, beer ( $4.9 \%$ ethanol), ethanol in water or $12.5 \%$ glucose in water as drinking fluids. All beverages excluding beer and the glucose drink were diluted to $9.5 \%$ ethanol. Red wine consumption significantly reduced the incidence of aortic atherosclerosis compared with controls, whilst ethanol, white wine and whisky provided only slight protection. Beer showed no effect at all. All the alcoholic beverages except beer also raised HDL. A more recent study using a hamster model was even more positive and found that diluted (beverage-water, 1:1) red wine and grape juice elicited a decrease in atherosclerosis and lipoprotein concentrations (even HDL), and when controlled for polyphenol content, grape juice was found to be more effective than red wine, either with or without alcohol (Vinson et al. 2001). Therefore phenolic constituents appear to be more effective than alcohol in reducing the incidence of experimental atherosclerosis, but most alcoholic beverages can increase HDL. However the greater efficiency of grape juice compared with wine, when controlled for polyphenol content, could highlight differential absorption parameters of the various polyphenols and addresses the problem of what are the truly active compounds in vivo.

Other animal studies appear to contradict some of these findings. Hayek et al. (1997) fed either catechin $(50 \mu \mathrm{g} / \mathrm{d}$ in $1.1 \%$ alcohol solution), quercetin $(50 \mu \mathrm{g} / \mathrm{d}$ in $1.1 \%$ alcohol solution) or red wine $(1 \cdot 1 \%$ alcohol, $0.5 \mathrm{ml} / \mathrm{d}$, i.e. $50 \mu \mathrm{g}$ catechin equivalent) to atherosclerotic, apo E-deficient mice for 6 weeks. They found no effect of any of the alcohol treatments on plasma lipids when compared with placebo. Yet when the lesion areas were investigated in the mice, the areas were smaller in the alcohol-treated groups than those in the control group by 39, 46 and $48 \%$ respectively for each treatment. In addition these authors showed that lesion size was directly associated with the in vitro uptake of LDL by macrophage cells and a reduced susceptibility of isolated LDL to oxidation and aggregation. A similar lack of effect on the plasma lipid profile was observed with experimental studies using Sprague-Dawley rats receiving one of four beverages $(35 \mathrm{ml} / \mathrm{d})$, i.e. red wine, dealcoholised red wine, $12 \%$ alcohol, and water with sucrose (Cestaro et al. 1996). However, in this study there was also no effect observed on the indices of peroxidation in plasma or erythrocytes. Neither of these studies showed the expected effect on HDL in rats or mice and only with mice was there any effect on LDL oxidation, which questions the usefulness of comparing results of animal studies (using different species) with the situation in human studies.

Hepatic damage (defined as degree of abnormal histological structure) in rats caused by 2 months of alcohol consumption was corrected by supplementing with grape polyphenols over the same period (Sun et al. 1999). The rats were fed daily diets that contained either: (1) no ethanol and no grape polyphenols, (2) $50 \mathrm{~g}$ ethanol/1 and no grape polyphenols, (3) no ethanol and $50 \mathrm{mg}$ grape polyphenols/l or (4) ethanol and grape polyphenols. Less hepatic damage was observed in the rats fed the diet with both alcohol and grape polyphenols than in the rats fed the diet with alcohol alone. The study suggests a protective role for grape polyphenols against alcohol damage but only when the two are consumed together.

In reality, animal studies are useful only up to a point. Lipoprotein metabolism is different in man compared with other species, especially rats (Chopra \& Thurnham, 1999), and this may explain the lack of effect of different alcoholic beverages on LDL oxidation and HDL concentrations reported by Cestaro et al. (1996). In contrast, man and rabbits have a similar fat metabolism where cholesteryl ester transfer protein (CETP) activity is unaffected by vitamin E supplementation (Liu et al. 1997), but in rats the CETP activity is suppressed (Shen et al. 1996). This is relevant to lipoprotein metabolism in atherosclerosis as an increased CETP level in the plasma is associated with decreased plasma HDL; therefore, increases in HDL seen with vitamin E supplementation in rats could be related to decreased CETP activity. Thus any extrapolation from experimental work to man should be considered with care. The effects of alcohol on hepatic morphology are also most probably subject to the same difficulties in interpretation, as alcohol metabolism may well differ between species and possibly within species as well. In man, there are different mutations of the gene for the enzyme alcohol dehydrogenase, the firststep enzyme involved in metabolising alcohol (Li et al. 2001). Previously it was observed that there were large individual and racial differences in blood and breath acetaldehyde (a product of the alcohol dehydrogenase reaction) after alcohol consumption, with individuals of Oriental origin having extremely high levels, and Caucasians low levels (Von Wartburg et al. 1983). This is due to the fact that a large percentage of those of Oriental origin have very low levels of aldehyde dehydrogenase, blocking alcohol metabolism at the stage of acetaldehyde formation. In all, it is wise to consider the limitations of extrapolating animal studies to man due to the large variation in genetic and metabolic reactions.

Lipid content and oxidative modification: in vivo human studies. Studies have been performed to investigate whether alcohol or polyphenols in wine confer protection against atherosclerosis. Evidence has been found to suggest that longterm and regular consumption of red wine, but not alcohol, inhibits LDL oxidation ex vivo (Kondo et al. 1994). Generally, supplementation trials of red and white wine are designed to allow observation of short-term changes that may be indicative of long-term protection against CHD, for example, of plasma lipids. Typically the trials supplement 
with $200-500 \mathrm{ml} / \mathrm{d}$ for approximately 2 weeks, but some for as long as 4 weeks. Longer trials are not generally performed as effects are seen within weeks on plasma lipids, and the ethics of supplementing alcoholic beverages for long periods of time must be considered. Trials that only supplement with single doses may not show effects within the monitoring period. For example, Cacetta et al. (2000) conducted a study involving a range of the beverages consumed on random and separate visits 1 week apart. Blood samples were taken at 0 , 1,2 and $4 \mathrm{~h}$ after consumption. No effect was reported from the consumption of red wine, de-alcoholised red wine or phenol-stripped red wine on serum or LDL oxidation. However these results might not be totally unexpected since LDL has a half-life of 2-3 d; thus beneficial effects of feeding polyphenols would take some time to appear before they might influence the composition of LDL.

Table 2 shows the results of five wine supplementation trials on changes in plasma lipid concentrations. The studies supplemented with a range of volumes of beverages, from 200 to $500 \mathrm{ml} / \mathrm{d}$, and ranged from 10 to $30 \mathrm{~d}$ duration. In the two studies where the effects of red wine on plasma LDL concentrations were measured, the effects were not consistent, with only one study indicating a reduction in LDL (Sharpe et al. 1995). Four out of the five studies showed an increase in HDL after supplementation with red wine. The fifth that did not show an increase was shorter and used less wine than the other four (Sharpe et al. 1995). Overall, the studies indicate that red wine consumption is effective in increasing HDL. Some of the studies also showed a similar effect on HDL with white wine, and a non-phenolic alcoholic beverage. In one study, grape juice (both with and without resveratrol enrichment) was used as a comparative supplement but no effect was seen on any lipid parameters measured (Goldberg et al. 1996). The lack of effect from the grape juices and the positive results from the white wines and non-phenolic alcoholic beverage suggest that alcohol in these cases was the most probable factor causing the effects on HDL. The mechanism by which this occurs is not known although there is some evidence to support a stimulation of the reverse cholesterol-transport pathway. One study has shown that the first two steps of this pathway (cellular cholesterol efflux and plasma cholesterol esterification) are stimulated by alcohol consumption (van Der Gaag et al. 2001).

The results from studies to determine the effects of wine supplements on susceptibility of LDL to peroxidation are mixed (Table 3). Five studies found no effect of either red or white wine or powdered red wine on LDL oxidation and four studies observed a decrease in the propensity for LDL to oxidise following the consumption of red wine. Positive results were seen with supplementation of at least $375 \mathrm{ml}$ red wine/d (or equivalent) for at least 2 weeks. Thus the lack of effect of red wine could be explained by the low volume of wine consumed over only a short period of time (Sharpe et al. 1995; Cacetta et al. 2000). Another study still had a negative outcome despite supplementing with $550 \mathrm{ml} / \mathrm{d}$ for 4 weeks. However, low-alcohol wines were used and this may explain the lack of effect, as the alcohol may be needed to act synergistically with the wine phenolics or potentially aid absorption into the bloodstream (de Rijke et al. 1996). Quercetin supplementation alone has also been shown to protect LDL from oxidation, indicating that a phenolic component of red wine can be effective taken without alcohol (Chopra et al. 2000). Comparisons have been made between the modes of administrating the red wine polyphenols (Nigdikar et al. 1998). The study showed a protective effect of red wine and its polyphenols against LDL peroxidation but the effect of the red wine extract seemed to depend on whether it is presented in an alcoholic medium. There is a commercial red wine extract known as Nutrivine ${ }^{\mathrm{TM}}$ (marketed by the Howard Foundation, Cambridge, UK), which can be taken either as a capsule or as a formulation to which water is added for drinking; both forms are equivalent to $375 \mathrm{ml}$ red wine. Studies on this extract have shown it has the ability to protect LDL from oxidation after supplementation for 2 weeks (Nigdikar \& Howard, 1997a).

There is a possibility that the protective effects of wine polyphenols may only be observed in hyperlipidaemic sub-

Table 2. Human supplementation studies: effects of wines and polyphenols on plasma lipid concentrations

\begin{tabular}{|c|c|c|c|}
\hline Study & Duration of study & Supplementation groups & Outcome \\
\hline Seigneur et al. (1990) & $15 d$ & $\begin{array}{l}\text { (1) Red wine }(500 \mathrm{ml} / \mathrm{d}) \\
\text { (2) White wine }(500 \mathrm{ml} / \mathrm{d})\end{array}$ & $\begin{array}{l}\text { White wine consumption was associated with increases } \\
\text { in total cholesterol, LDL and HDL, but red wine only } \\
\text { induced an increase in HDL }\end{array}$ \\
\hline Lavy et al. (1994) & 2 weeks & $\begin{array}{l}\text { (1) Red wine }(400 \mathrm{ml} / \mathrm{d}) \\
\text { (2) White wine }(400 \mathrm{ml} / \mathrm{d})\end{array}$ & $\begin{array}{l}\text { Increased plasma HDL, apo A-I and triacylglycerol with red } \\
\text { wine consumption, not white wine }\end{array}$ \\
\hline Sharpe et al. (1995) & $10 \mathrm{~d}$ cross-over trial & $\begin{array}{l}\text { (1) Red wine }(200 \mathrm{ml} / \mathrm{d}) \\
\text { (2) White wine }(200 \mathrm{ml} / \mathrm{d})\end{array}$ & $\begin{array}{l}\text { No differences between treatments for total cholesterol, } \\
\text { triacylglycerol and HDL. Red wine reduced LDL } \\
\text { cholesterol and lipoprotein A. Both wines reduced LDL } \\
\text { apo B and increased LDL:apo B ratio }\end{array}$ \\
\hline Goldberg et al. (1996) & $\begin{array}{l}4 \text { weeks cross-over } \\
\text { trial }\end{array}$ & $\begin{array}{l}\text { (1) Red wine }(375 \mathrm{ml} / \mathrm{d}) \\
\text { (2) White wine }(375 \mathrm{ml} / \mathrm{d}) \\
\text { (3) Grape juice }(500 \mathrm{ml} / \mathrm{d}) \\
\text { (4) Grape juice plus } \\
\text { resveratrol }(500 \mathrm{ml} / \mathrm{d})\end{array}$ & $\begin{array}{l}\text { No effect of grape juice or that enriched with resveratrol. } \\
\text { Both wines raised plasma HDL, apo A-I and apo A-II } \\
\text { concentrations and the apo A-I:apo B ratio }\end{array}$ \\
\hline Estruch (2000) & $30 \mathrm{~d}$ cross-over trial & $\begin{array}{l}\text { (1) Red wine (equivalent to } \\
30 \mathrm{~g} \text { ethanol/d) } \\
\text { (2) Alcoholic beverage low in } \\
\text { polyphenols (equivalent } \\
\text { to } 30 \mathrm{~g} \text { ethanol/d) }\end{array}$ & $\begin{array}{l}\text { Both red wine and the alcoholic beverage increased } \\
\text { plasma HDL }\end{array}$ \\
\hline
\end{tabular}


Table 3. Human supplementation studies: effects of wines and polyphenols on lipid and serum oxidation

\begin{tabular}{|c|c|c|}
\hline Study & Duration of study & Supplementation groups \\
\hline Sharpe et al. (1995) & $10 \mathrm{~d}$ cross-over trial & $\begin{array}{l}\text { (1) Red wine }(200 \mathrm{ml} / \mathrm{d}) \\
\text { (2) White wine }(200 \mathrm{ml} / \mathrm{d})\end{array}$ \\
\hline Fuhrman et al. (1995) & 2 weeks & $\begin{array}{l}\text { (1) Red wine }(400 \mathrm{ml} / \mathrm{d}) \\
\text { (2) White wine }(400 \mathrm{ml} / \mathrm{d})\end{array}$ \\
\hline
\end{tabular}

de Rijke et al. (1996) 4 weeks

Carbonneau et al. (1997) 2 weeks

Nigdikar et al. (1998) 2 weeks

Chopra et al. (2000) 2 weeks

Estruch (2000)

$30 \mathrm{~d}$ cross-over trial

Cacetta et al. (2000)

Cacetta et al. (2001)
2 weeks

\begin{abstract}
Random and separate visits 1 week apart; twelve subjects
\end{abstract}

(1) Low alcohol red wine $(550 \mathrm{ml} / \mathrm{d})$

(2) Low alcohol white wine $(550 \mathrm{ml} / \mathrm{d})$

(1) Powdered red wine supplement ( $0.33 \mathrm{~g} /$ capsule; six times daily)

(1) Red wine $(375 \mathrm{ml} / \mathrm{d})$

(2) White wine $(375 \mathrm{ml} / \mathrm{d})$

(3) Red wine polyphenol powder capsules $(1 \mathrm{~g} / \mathrm{d})$

(4) Same powder dissolved in white wine

(5) Control alcoholic drink (40 $\mathrm{g}$ ethanol/d)

(1) Red wine extract equivalent to $375 \mathrm{ml} / \mathrm{d}$

(2) Quercetin supplementation Both treatments increased the lag time for the Cu mediated (30 mg/d)

(1) Red wine (equivalent to $30 \mathrm{~g}$ ethanol/d; about $250 \mathrm{ml} / \mathrm{d}$ )

(2) Alcoholic beverage low in polyphenols (equivalent to $30 \mathrm{~g}$ ethanol/d)

(1) Red wine

(2) Dealcoholised red wine

(3) Phenol-stripped red wine $(5 \mathrm{ml} / \mathrm{kg}$ body weight over $30 \mathrm{~min}$ )

(1) Red wine

(2) White wine

(3) Dealcoholised red wine
No effect with either treatment on LDL oxidation

Red wine increased erythrocyte membrane fluidity

Red wine consumption reduced while white wine consumption increased susceptibility of plasma to lipid peroxidation. White wine consumption also increased susceptibility of LDL to lipid peroxidation

No effect of either wine on Cu mediated oxidation of LDL

No change in LDL resistance to oxidation

The lag time for Cu mediated oxidation of LDL was increased by:

the red wine powder (14.2 $\mathrm{min}, 27 \%)$

the red wine powder in white wine $(11.7 \mathrm{~min}, 21 \%)$

the red wine $(17.8 \mathrm{~min}, 31 \%)$ oxidation of LDL

Red wine decreased parameters of serum oxidation and the propensity for LDL to undergo lipid peroxidation

No effect on serum or LDL oxidation with any treatment

No reduction in lipid peroxidation (as measured with F2-isoprostane) with red or white wine consumption, but a reduction with dealcoholised red wine was seen jects (Chopra \& Thurnham, 1999). Hypercholesterolaemia is believed to be associated with elevated plasma vitamin E, as a positive correlation between concentrations of these two components is normally found in plasma (Thurnham et al. 1986). However, the amount of vitamin E may still not be adequate. A high plasma lipid level allows more lipid to be available for oxidative modification by free radical species; therefore, hyperlipidaemia can lead to increased oxidative damage (Prasad \& Kalra, 1993). Most studies reported in the literature were done with normolipidaemic subjects and so potential benefits from wines may have been marginal and not significant. Subjects with elevated lipid status or in a disease state where oxidative damage is being caused may have a more pronounced response to polyphenol supplementation.

\section{Serum antioxidant capacity}

In an attempt to determine whether wine consumption increases serum antioxidant capacity, four different methods have been used to measure plasma antioxidant activity following supplementation. Five studies have reported results; two using red wine, one using red grape juice, one using a powdered red wine supplement and one using alcohol-free red wine (Table 4). In all cases there was an increased antioxidant activity following consumption of the treatment. Comparable white wine supplementation, both with and without alcohol, gave no significant increases in antioxidant activity. Single doses of red wine $(113 \mathrm{ml}$ alcohol-free and $300 \mathrm{ml}$ alcohol-containing wine) were effective within $1 \mathrm{~h}$ of consumption (Whitehead et al. 1995; Serafini et al. 1998). Consumption of $300 \mathrm{ml}$ alcoholised red wine was still effective after $4 \mathrm{~h}$ (Cao et al. 1998). Grape juice was also effective within $1 \mathrm{~h}$ of consumption, and this was maintained and increased after $7 \mathrm{~d}$ of supplementation (Day et al. 1997). Serafini et al. (1998) observed parallel increases in plasma phenolic content to increases in total plasma antioxidant capacity with alcohol-free red wine consumption, but not white wine. So polyphenols supplemented in vivo in different forms, i.e. non-alcoholic wine, red wine powder and grape juice, all had a positive effect on serum antioxidant capacity despite differences in their methods of measuring the change. These studies 
Table 4. Studies showing effects of wines and polyphenols on plasma antioxidant capacity in man

\begin{tabular}{|c|c|c|c|}
\hline Study & Study design & Supplementation groups & Outcome \\
\hline Whitehead et al. (1995) & $\begin{array}{l}\text { Single dose; nine } \\
\text { subjects }\end{array}$ & $\begin{array}{l}\text { (1) } 300 \mathrm{ml} \text { red wine } \\
\text { (2) } 300 \mathrm{ml} \text { white wine }\end{array}$ & $\begin{array}{l}\text { SAOC increased significantly }(P<0.005) \text { compared with } \\
\text { baseline with red wine }(18 \text { and } 11 \% \text { after } 1 \text { and } 2 \mathrm{~h} \\
\text { respectively). White wine gave no significant increases } \\
\text { ( } 4 \text { and } 7 \% \text { after } 1 \text { and } 2 \text { h respectively) }\end{array}$ \\
\hline Day et al. (1997) & $7 \mathrm{~d}$; seven subjects & $\begin{array}{l}\text { (1) } 125 \mathrm{ml} \text { concentrated red } \\
\text { grape juice } / \mathrm{d}\end{array}$ & $\begin{array}{l}\text { SAOC increased by } 8.4 \% \text { after } 60 \text { min on day } 1 \\
(P<0.005) \text { and by } 11.3 \%(P<0.05) \text { on day } 8\end{array}$ \\
\hline Carbonneau et al. (1997) & $\begin{array}{l}\text { 2-week } \\
\text { supplementation; } \\
\text { twenty subjects }\end{array}$ & $\begin{array}{l}\text { (1) Powdered red wine } \\
\text { supplement } \\
(0.33 \text { g/capsule; } \\
\text { six times daily) }\end{array}$ & $\begin{array}{l}\text { Significant increase }(8.7 \%, P=0.01) \text { in total plasma } \\
\text { antioxidant capacity (measured with a chemiluminescence } \\
\text { reaction) but no change in LDL resistance to oxidation }\end{array}$ \\
\hline Serafini et al. (1998) & $\begin{array}{l}\text { Single dose; } \\
\quad \text { ten subjects }\end{array}$ & $\begin{array}{l}\text { (1) Alcohol-free red wine } \\
\quad(113 \mathrm{ml}) \\
\text { (2) Alcohol-free white wine } \\
(113 \mathrm{ml}) \\
\text { (3) Water (control) }(113 \mathrm{ml})\end{array}$ & $\begin{array}{l}\text { Alcohol-free red wine increased total plasma antioxidant } \\
\text { capacity by } 14 \% \text { after } 50 \text { min (measured by TRAP) with } \\
\text { parallel increases in plasma polyphenolic content. No } \\
\text { response from the other two treatments }\end{array}$ \\
\hline Cao et al. (1998) & $\begin{array}{l}\text { Single dose; } \\
\quad \text { eight subjects }\end{array}$ & (1) $300 \mathrm{ml}$ red wine & $\begin{array}{l}\text { SAOC increased by } 11 \text { and } 7 \% \text { after } 4 \mathrm{~h} \text { when measured by } \\
\text { FRAP and ORAC respectively }\end{array}$ \\
\hline
\end{tabular}

SAOC, serum antioxidant capacity; TRAP, total radical-trapping antioxidant parameter ( $\mu$ mol peroxyl radicals trapped/litre of plasma); FRAP, ferric-reducing ability of plasma; ORAC, oxygen radical absorbance capacity.

appear to indicate the effective component in this case might not be alcohol, but rather polyphenol concentration.

The effects of grape juice may not be completely analogous to the non-alcoholic content of red wine, as grape juice does not contain flavonoids from the skin and seeds of the grape whereas red wine does. The difference in the two preparations is particularly true for resveratrol as it is typically found in the grape skin. It should also be noted that phenolics are labile compounds, and so the de-alcoholisation process used to remove alcohol from the wine may cause chemical alterations that makes comparison with the native wine potentially biased. Thus using grape juice as a substitute for de-alcoholised red wine may not be appropriate (Waterhouse \& Walzem, 1998). It should also be noted that red wine powder may not be consistent in its composition because each powder can come from a different wine and therefore can affect supplementation study results. For example, Carbonneau et al. (1997) used a red wine powder low in catechins and proanthocyanidins compared with standard red wine and found no effect on LDL oxidation. In contrast a similar study from our group did show an inhibitory effect on LDL oxidation by the non-alcoholic red wine extract Nutrivine ${ }^{\mathrm{TM}}$ (Chopra et al. 2000).

\section{Vasculature, smooth muscle cells and nitric oxide production}

Endothelial dysfunction is linked to many of the risk factors for CHD including hypercholesterolaemia, smoking, and familial history of premature CHD. Also many coronary risk factors are known to reduce NO availability, making NO a popular intermediate end-point for assessing atherogenic risk (Vogel, 2003). Control of vascular relaxation is endothelium dependent and is mediated by NO (Cuevas et al. 2000). The mechanisms by which polyphenols could potentially influence NO production and release are: (1) an increased release of NO from intracellular stores; (2) the preservation and/or stabilisation of $\mathrm{NO}$ released under basal conditions; (3) the stimulation of NO synthase activity (Cishek et al. 1997). The latter mechanism has support from a study performed on rabbit aortic rings, which found that acute exposure to polyphenols produces endothelium-dependent relaxation that can be abolished by inhibiting NO synthase activity (Cishek et al. 1997). Another suggested mechanism is the selective inhibition of NO-related oxidation and nitration reactions leading to less peroxynitrate production (Wippel et al. 2004).

Table 5 shows a summary of some studies performed in this area. Where endothelium-dependent relaxation of aortic rings was used as an end-point for the in vitro experiment, the results were generally positive. Red wine polyphenols tended to induce vessel relaxation in vitro (Andriambeloson et al. 1997), but only at levels of $10 \mathrm{mg} / \mathrm{l}$ and above (Deckert et al. 2002). One study did not find this effect, but the dose used was only at levels equivalent in alcohol to moderate wine consumption (15 mM-alcohol in blood postconsumption) (Rendig et al. 2000). When specific phenolics were tested alone in the same manner, not all were seen to elicit an effect. Although quercetin alone has been shown to induce dose-related vaso-relaxation (Rendig et al. 2000), other more abundant phenolics gave no response, i.e. gallic, benzoic, vanillic, $p$-coumaric and caffeic acids and epicatechin (Andriambeloson et al. 1997). A minor flavanol of red wine called leucocyanidol was seen to induce complete vessel relaxation, but the major flavanol catechin did not give a similar effect (Andriambeloson et al. 1997). It was also shown that some of these polyphenols could cause an endothelium-dependent increase in NO content in the rat aorta. This was corroborated by a very recent study that found that red wine increased the expression of human endothelial NO production in vitro (Wallerath et al. 2003). The effects on NO production were seen with French wines, but not German wines, indicating a specific substance(s) present in one and not the other may be responsible. For instance, this could be leucocyanidol, or another minor and as yet unmeasured phenolic. However, it should also be noted that the wine concentrations used for this experiment might not reflect physiologically relevant levels (Vogel, 
Table 5. Studies showing effects of wines and polyphenols on endothelium-dependent relaxation and nitric oxide

\begin{tabular}{|c|c|c|c|c|}
\hline Study & Measures & Substance tested & Negative outcome & Positive outcome \\
\hline $\begin{array}{l}\text { Andriambeloson } \\
\text { et al. (1997) }\end{array}$ & $\begin{array}{l}\text { In vitro vaso- } \\
\text { relaxation of } \\
\text { thoracic rat aorta } \\
\text { in organ bath } \\
\text { studies }\end{array}$ & $\begin{array}{l}\text { Polyphenolic compounds } \\
\text { (powder derived from } 1 \text { litre } \\
\text { red wine (mg/g): } \\
\text { catechins and } \\
\text { proanthocyanidins, 100; } \\
\text { anthocyanins, 64; flavonols, 5; } \\
\text { phenolic acids, 8.7) and } \\
\text { leucocyanidol (flavan-3,4-ol, } \\
\text { a polyphenol found in wine) }\end{array}$ & $\begin{array}{l}\text { Catechin when tested alone did } \\
\text { not induce complete vessel } \\
\text { relaxation }\end{array}$ & $\begin{array}{l}\text { Red wine polyphenolic } \\
\text { compounds at } 0.01 \mathrm{~g} / \mathrm{l} \text { and } \\
\text { specifically leucocyanidol, } \\
\text { when tested alone, induced } \\
\text { complete vessel relaxation }\end{array}$ \\
\hline $\begin{array}{l}\text { Andriambeloson } \\
\text { et al. (1998) }\end{array}$ & $\begin{array}{l}\text { In vitro endothelium- } \\
\text { dependent } \\
\text { relaxation of the } \\
\text { thoracic aorta of } \\
\text { Wistar rats }\end{array}$ & $\begin{array}{l}\text { Individual and fractions of red } \\
\text { wine phenolic compounds }\end{array}$ & $\begin{array}{l}\text { Gallic, benzoic, vanillic, } \\
p \text {-coumaric and caffeic acids } \\
\text { and }(+)-\text { epicatechin gave } \\
\text { no response }\end{array}$ & $\begin{array}{l}\text { Comparable concentrations of } \\
\text { anthocyanins and oligomeric- } \\
\text { condensed tannins fractionated } \\
\text { from red wine showed similar } \\
\text { effects as the full complement } \\
\text { of red wine polyphenolic } \\
\text { compounds }\end{array}$ \\
\hline $\begin{array}{l}\text { Deckert et al. } \\
\text { (2002) }\end{array}$ & $\begin{array}{l}\text { In vitro } \\
\text { endothelium- } \\
\text { dependent } \\
\text { relaxation of } \\
\text { rabbit arteries }\end{array}$ & $\begin{array}{l}\text { Red wine polyphenols from } \\
\text { Cabernet Sauvignon wine }\end{array}$ & $\begin{array}{l}\text { Concentration of } 1 \mathrm{mg} / \mathrm{l} \text { had } \\
\text { no effect on contraction of } \\
\text { aortic rings }\end{array}$ & $\begin{array}{l}\text { Concentrations at } 10 \text { and } \\
100 \mathrm{mg} / \mathrm{l} \text { had significant } \\
\text { vaso-relaxation effect }\end{array}$ \\
\hline $\begin{array}{l}\text { Wallerath et al. } \\
\text { (2003) }\end{array}$ & $\begin{array}{l}\text { In vitro measurement } \\
\text { of expression of } \\
\text { human endothelial } \\
\text { NO synthase }\end{array}$ & $\begin{array}{l}\text { Various red wines from Germany } \\
\text { and France, diluted } 1,3 \text { and } \\
10 \%(\mathrm{v} / \mathrm{v})\end{array}$ & $\begin{array}{l}\text { German red wines showed little } \\
\text { or no effect on endothelial-type } \\
\text { NO synthase expression }\end{array}$ & $\begin{array}{l}\text { French red wines up regulated } \\
\text { expression of endothelial-type } \\
\text { NO synthase. }\end{array}$ \\
\hline
\end{tabular}

2003), as wines were simply diluted to 1,3 and $10 \%$ before introduction to cells and no measures of phenolic concentrations were made. In general, the studies indicated that some compounds from wine could enhance the synthesis of NO, i.e. they possessed endothelium-dependent vaso-relaxing abilities.

Endothelial function in response to wine has also been studied in man. In a $30 \mathrm{~d}$, red wine supplementation trial, it was found that the presence of wine with a diet prevented fat-related changes in endothelial function. Endothelial function was measured by flow-mediated dilatation of the brachial artery with high-resolution ultrasound. In the absence of wine, high-fat diets (39.5\% total energy) in six volunteers depressed function $(-2 \cdot 9$ (SD $2 \cdot 1) \%)$ when compared with a diet containing fat as only $27 \%$ total energy where the change was $+3 \cdot 1$ (SD 3.9) \% (Cuevas et al. 2000). This difference was not observed when $240 \mathrm{ml}$ red wine/d was supplemented with both high-fat $(6 \cdot 6(\mathrm{SD} 2 \cdot 2) \cdot \%)$ and control (5.8 (SD 4.6) \%) diets. However, increased NO release from endothelium and macrophages can also cause increased LDL lipid peroxidation, therefore increasing the potential atherogenic properties of LDL (Graham et al. 1993; Hazen et al. 1999; Podrez et al. 1999).

A few studies have also investigated possible links between blood pressure and polyphenol consumption. One study found a decreased blood pressure with a phenolic beverage (grape juice and vinegar mix) in rats (Sugiyama et al. 2003). Similar effects have been seen with supplementation with single phenolics such as ferulic acid in hypertensive rats (Suzuki et al. 2002).
Flavonoids have been thought to modulate monocyte adhesion to endothelial cells during the inflammatory process of atherosclerosis (Harbourne \& Williams, 2000). However, a new study has cast doubt on the ability of certain flavonoids to directly affect endothelial cells (Koga \& Meydani, 2001). Human aortic endothelial cells were pretreated in vitro with either catechin, catechin metabolites, quercetin or quercetin metabolites. Only the catechin metabolites and quercetin (but not its metabolites) inhibited monocyte adhesion to endothelial cells following treatment by $\mathrm{H}_{2} \mathrm{O}_{2}$ to create damage to the cells. It is suggested that conjugated quercetin metabolites have a reduced or abolished biological activity and that the degree of this change depends on the nature and position of the substitutions (Day et al. 2000). However, it is possible that in vivo $\beta$-glucuronidase released from neutrophils, especially at the site of inflammation, may deconjugate phenolic metabolites in serum and release the aglycone (Shimoi et al. 2000). Therefore extrapolation of in vitro findings to an in vivo situation may be physiologically relevant but the precise amounts of phenolic metabolites in vivo, their half-lives and potential reactivity require further investigation.

In vivo supplementation involves the measurement of a variety of physiological rather than cellular responses that in vitro experimentation would provide. Transforming growth factor $\beta$ inhibits the growth of arterial smooth muscle cells, and therefore can potentially assist in preventing atherosclerosis (McCaffrey, 2000). Concentrations of plasma transforming growth factor $\beta$ are raised approximately 
four-fold in vivo after the consumption of modest amounts of red wine polyphenols in wine or in capsule form, compared with after white wine consumption (Nigdikar \& Howard, 1997b). A recent study also confirmed that red wine polyphenols would inhibit the growth of rat aortic smooth muscle cells in vitro. When investigating the mechanism, the workers found that red wine polyphenols down regulated the expression of the cyclin A gene, a gene that is critical in DNA replication and cell cycle regulation. The authors suggest that inhibition of the cyclin A gene may be responsible for the inhibition of smooth muscle cell growth (Iijima et al. 2000) and this was reinforced by a later study that more fully investigated the gene (Iijima et al. 2002). These data appear to support the idea that polyphenols do act on aortic smooth muscle cells and that transforming growth factor $\beta$ and the cyclin A gene are either directly or indirectly involved in the mechanisms.

\section{Platelets}

Platelet ability to aggregate is an important factor in CHD. In vitro, alcohol has a similar effect to aspirin in its ability to decrease secondary aggregation of platelets in response to ADP. A suggestion has been made that since wine is generally consumed with food, the alcohol is absorbed slowly, therefore it can have a longer effect on the body's metabolism; for example, on blood platelet reactivity at a time when lipid levels would be high (Renaud \& de Lorgeril, 1992). In vivo inhibition of platelet aggregation by moderate alcohol consumption was noted in the Caerphilly Prospective Heart Disease Study (Renaud et al. 1992) and, later, in an acute consumption study when both platelet-rich plasma and whole blood were examined (Zhang et al. 2000).

Both wines and grape juices can affect platelet aggregation in man, by reducing plasma thromboxane $\mathrm{B}_{2}$ concentration and the concentration of ADP and thrombin available for platelet aggregation. Table 6 shows seven studies, five of which found lower platelet aggregation with wine phenolics both ex vivo and in vitro. One study found that red wine ingestion reduced but, surprisingly, pure alcohol increased platelet aggregation (Seigneur et al. 1990). It was suggested that this effect was due to the presence of aspirin in red wine but red wine has been shown to contain only negligible amounts of aspirin (Janssen et al. 1994).

Table 6. Studies showing effects of wines and polyphenols on platelet aggregation and related factors

\begin{tabular}{|c|c|c|c|}
\hline Study & Measures & Substances tested & Outcome \\
\hline Landolfi et al. (1984) & $\begin{array}{l}\text { Inhibition of } \\
\text { cyclo-oxygenase } \\
\text { activity and human } \\
\text { platelet aggregation } \\
\text { and the platelet } \\
\text { cyclic AMP response } \\
\text { to } \mathrm{PGI}_{2} \text { in vitro }\end{array}$ & Multiple flavonoids & $\begin{array}{l}\text { Of flavonoids tested, most could inhibit cyclo-oxygenase } \\
\text { activity but only flavone, chrysin, apigenin and phloretin } \\
\text { inhibited platelet aggregation to any extent. The } \\
\text { flavonoid glycosides and flavonone derivatives had } \\
\text { no effect on platelet aggregation. Apigenin, chrysin } \\
\text { and flavone reduced, while myricetin and quercetin } \\
\text { increased, the platelet cyclic AMP response to } \mathrm{PGI}_{2}\end{array}$ \\
\hline Seigneur et al. (1990) & $\begin{array}{l}\text { ADP- or adrenaline- } \\
\text { induced human } \\
\text { platelet aggregation } \\
\text { ex vivo }\end{array}$ & $\begin{array}{l}\text { White or red wine or a } \\
\text { synthetic alcoholic non- } \\
\text { polyphenolic wine ingestion } \\
(0.5 \text { litres/d) for } 15 \mathrm{~d}\end{array}$ & $\begin{array}{l}\text { Red wine reduced ADP-induced platelet aggregation } \\
\text { but pure alcohol enhanced ADP- and adrenaline-induced } \\
\text { platelet aggregation }\end{array}$ \\
\hline Demrow et al. (1995) & $\begin{array}{l}\text { Cyclic flow reductions } \\
\text { in canine coronary } \\
\text { arteries }\end{array}$ & $\begin{array}{l}\text { Intravenous and intragastric } \\
\text { administration of grape } \\
\text { juice and red wine }\end{array}$ & $\begin{array}{l}\text { Eliminated reductions in cyclic flow as a measure of } \\
\text { reduction of thrombus formation. For a full } \\
\text { explanation, see p. } 125\end{array}$ \\
\hline $\begin{array}{l}\text { Pace-Asciak et al. } \\
\quad \text { (1996) }\end{array}$ & $\begin{array}{l}\text { Aggregation of freshly } \\
\text { washed human } \\
\text { platelets ex vivo by } \\
\text { ADP and thrombin } \\
\text { plasma } \mathrm{TxB}_{2} \\
\text { concentration }\end{array}$ & $\begin{array}{l}4 \text { weeks of moderate grape } \\
\text { juice, grape juice enriched } \\
\text { with resveratrol, white or } \\
\text { red wine consumption }\end{array}$ & $\begin{array}{l}\text { Aggregation strongly inhibited by red wine, unaffected } \\
\text { by white wine and only moderately inhibited by } \\
\text { commercial grape juice and juice enriched with } \\
\text { trans-resveratrol. Reductions of } 52.5 \text { and } 59.4 \% \text { in } \\
\text { plasma } T x B_{2} \text { concentration for white and red wine } \\
\text { consumption respectively }\end{array}$ \\
\hline Janssen et al. (1998) & $\begin{array}{l}\text { Inhibition of collagen- } \\
\text { and ADP-induced } \\
\text { aggregation in both } \\
\text { human platelet-rich } \\
\text { plasma and washed } \\
\text { platelets in vitro }\end{array}$ & $\begin{array}{l}\text { Six concentrations of } \\
\text { quercetin-3-glucoside, } \\
\text { quercetin aglycone, } \\
\text { apigenin aglycone and } \\
\text { catechin }\end{array}$ & $\begin{array}{l}\text { Quercetin and apigenin inhibited collagen- and } \\
\text { ADP-induced aggregation in both platelet-rich plasma } \\
\text { and washed platelets by } 80-97 \%\end{array}$ \\
\hline Janssen et al. (1998) & $\begin{array}{l}\text { Platelet aggregation, } \\
\mathrm{TxB}_{2} \text { production, } \\
\text { factor VII and other } \\
\text { haemostatic factors } \\
\text { in human subjects } \\
\text { ex vivo }\end{array}$ & $\begin{array}{l}\text { Supplementation with } 200 \mathrm{~g} \\
\text { onions/d (about } 114 \mathrm{mg} \\
\text { quercetin/d) or } 5 \mathrm{~g} \text { dried } \\
\text { parsley/d (about } 84 \mathrm{mg} \\
\text { apigenin/d) for } 7 \mathrm{~d}\end{array}$ & $\begin{array}{l}\text { No effects on platelet aggregation, } \mathrm{TxB}_{2} \text { production, factor } \\
\text { VII or other haemostatic factors were observed }\end{array}$ \\
\hline Pignatelli et al. (2000) & $\begin{array}{l}\text { Inhibition in vitro of } \\
\text { collagen-induced } \\
\text { human platelet } \\
\text { aggregation and } \\
\text { platelet adhesion } \\
\text { to collagen }\end{array}$ & $\begin{array}{l}\text { Varying concentrations of } \\
\text { catechin and quercetin }\end{array}$ & $\begin{array}{l}\text { Catechin at } 50-100 \mu \mathrm{mol} / / \text { and } 10-20 \mu \mathrm{mol} \text { quercetin/l } \\
\text { inhibited collagen-induced platelet aggregation and } \\
\text { platelet adhesion to collagen. When the two were } \\
\text { combined at concentrations that did not give any } \\
\text { reaction singly (i.e. } 25 \mu \mathrm{mol} \text { catechin/l and } 5 \mu \mathrm{mol} \\
\text { quercetin/l), significant effects were observed }\end{array}$ \\
\hline
\end{tabular}

$\mathrm{PGI}$, prostacyclin; $\mathrm{TxB}_{2}$, thromboxane $\mathrm{B}_{2}$. 
Thrombus formation can cause cyclic reductions in coronary blood flow and experiments have shown an elimination of such reductions following intravenous and intragastric administration of grape juice and red wine (Demrow et al. 1995). Supplementation studies have shown that platelet aggregation was strongly inhibited by red wine, moderately inhibited by grape juice and unaffected by white wine. One animal study has found that platelet aggregation was reduced by ethanol, red wine and white wine in rats, but when the beverages were withdrawn, rats that had consumed red wine did not exhibit the plateletrebound effect observed hours after drinking alcohol, which has been associated with stroke in man (Ruf et al. 1995). Overall, the effects of alcohol on platelet aggregation appear to be enhanced by wine or grape polyphenols.

It has also been reported that some of the individual flavonoids are effective in inhibiting platelet aggregation. Table 6 describes studies that have tested the effects of individual and combinations of different polyphenols. Quercetin and apigenin have been shown to inhibit collagen- and ADP-induced aggregation but the effect was only seen at phenolic concentrations higher than would be expected to occur in vivo (Janssen et al. 1998). The authors investigated the physiological importance of the phenolics by using a feeding study with onions (high in quercetin) and dried parsley (high in apigenin) but there were no effects on platelet aggregation or thromboxane $\mathrm{B}_{2}$ production in vivo. Another interesting study using catechin and quercetin found that when the two flavonoids were combined in vitro at concentrations that did not give any reaction singly (i.e. $25 \mu \mathrm{mol}$ catechin/l and $5 \mu \mathrm{mol}$ quercetin/l), significant effects were observed on the inhibition of collagen-induced platelet aggregation and platelet adhesion to collagen (Pignatelli et al. 2000). The authors suggest that flavonoids may well act synergistically to inhibit platelet aggregation, and that this may be relevant after red wine consumption as the circulating concentration of each wine flavonoid is often lower than previously found to be effective to influence platelet activity.

\section{Conclusion}

Wine has been part of human culture and diet for many thousands of years and will probably continue to be for many more to come. Despite tremendous research input in this area in the past decade, we still have a great distance to cover in our understanding of the health benefits of wine. Although we know a lot more about the phenolic components of red wine, we still do not know whether the components have individual functions and which are the most important. Very little research has been done on the metabolism and biological activities of phenolics at cellular, molecular and biochemical levels. Further research is therefore required, especially human in vivo supplementation studies, with pure and mixtures of flavonoid compounds to identify the biological activities of their metabolites.

\footnotetext{
'It is a great error to consider a heavy tax on wine as a tax on luxury. On the contrary it is a tax on the health of our citizens.'
}

Thomas Jefferson (Statesman)

\section{Acknowledgements}

Karen Cooper is funded by the Howard Foundation, Cambridge, UK and DENI, Northern Ireland.

\section{References}

Adrian M, Jeandet P, Breuil AC, Levite D, Debord S \& Bessis R (2000) Assay of resveratrol and derivative stilbenes in wines by direct injection high performance liquid chromatography. American Journal of Enology and Viticulture 51, 37-41.

Andriambeloson E, Kleshyov AL, Muller B, Beretz A, Stoclet J-C \& Andriantsitohaina R (1997) Nitric oxide production and endothelium-dependent vasorelaxation induced by wine polyphenols in rat aorta. British Journal of Pharmacology 120, 1053-1058.

Andriambeloson E, Magnier C, Haan-Archipoff G, Lobstein A, Anton R, Beretz A, Stoclet J-C \& Andriantsitohaina R (1998) Natural dietary polyphenolic compounds cause endothelialdependent vasorelaxation in rat thoracic aorta. Journal of Nutrition 128, 2324-2333.

Aviram M (1996) Interaction of oxidised low density lipoprotein with macrophages in atherosclerosis, and the antiatherogenicity of antioxidants. European Journal of Clinical Chemistry and Clinical Biochemistry 34, 599-608.

Blache D, Durand P, Prost M \& Loreau N (2002) (+)-Catechin inhibits platelet hyperactivity induced by an acute iron load in vivo. Free Radical Biology and Medicine 33, 1670-1680.

Bors W, Heller W, Michel C \& Saran M (1990) Flavonoids as antioxidants: determination of radical-scavenging efficiencies. Methods in Enzymology 186, 343-355.

Brand K, Page S, Rogler G, Bartsch A, Brandl R, Knuechel R, Page M, Kaltschmidt C, Baeuerle PA \& Neumeier D (1996) Activated transcription factor nuclear factor- $\kappa \mathrm{B}$ is present in atherosclerotic lesions. Journal of Clinical Investigation 97, $1715-1722$.

Bravo L (1998) Polyphenols: chemistry, dietary sources, metabolism, and nutritional significance. Nutrition Reviews 56, 317-333.

Cacetta RA, Croft KD, Beilin LJ \& Puddey IB (2000) Ingestion of red wine significantly increases plasma phenolic acid concentrations but does not acutely affect ex vivo lipoprotein oxidisability. American Journal of Clinical Nutrition 71, 67-74.

Cacetta R, Burke V, Mori TA, Beilin JL, Puttey IB \& Croft KD (2001) Red wine polyphenols in the absence of alcohol reduce lipid peroxidative stress in smoking subjects. Free Radical Biology and Medicine 30, 636-642.

Cao G, Russell RM, Lischner N \& Prior RL (1998) Serum antioxidant capacity is increased by consumption of strawberries, spinach, red wine or vitamin C in elderly women. Journal of Nutrition 128, 2383-2390.

Cao G \& Prior RL (2000) Red wine in moderation: potential health benefits independent of alcohol. Nutrition in Clinical Care 3, 76-82.

Carbonneau M-A, Léger CL, Monnier L, Michel F, Fouret G, Dedieu F \& Descomps B (1997) Supplementation with wine phenolic compounds increases the antioxidant capacity of plasma and vitamin E of low-density lipoprotein without changing the lipoprotein $\mathrm{Cu} 2+$-oxidisability: possible explanation by phenolic location. European Journal of Clinical Nutrition 51, 682-690.

Carrero P, Ortega H, Martínez-Botas J, Gómez-Coronado D \& Lasunción MA (1998) Flavonoid-induced ability of minimally modified low-density lipoproteins to support lymphocyte proliferation. Biochemical Pharmacology 55, 1125-1129.

Cestaro B, Simonetti P, Cervato G, Brusamolino A, Gatti P \& Testolin G (1996) Red wine effects on peroxidation indexes of 
rat plasma and erythrocytes. International Journal of Food Sciences and Nutrition 47, 181-189.

Chai Y-C, Binion DG, Macklis R \& Chisholm GM (2002) Smooth muscle cell proliferation induced by oxidised LDL-borne lysophosphatidylcholine: evidence for FGF-2 release from cells not extracellular matrix. Vascular Pharmacology 38, 229-237.

Chatenoud L, Negri E, La Vecchia C, Volpato O \& Franceschi S (2000) Wine drinking and diet in Italy. European Journal of Clinical Nutrition 54, 177-179.

Chopra M, Fitzsimmons PEE, Strain JJ, Thurnham DI \& Howard AN (2000) Nonalcoholic red wine extract and quercetin inhibit LDL oxidation without affecting plasma antioxidant vitamin and carotenoid concentrations. Clinical Chemistry 46, 1162-1170.

Chopra M \& Thurnham DI (1999) Antioxidants and lipoprotein metabolism. Proceedings of the Nutrition Society 58, 663-671.

Chung KT, Wong TY, Wei C-I \& Huang Y-W (1998) Tannins and human health: a review. Critical Reviews in Food Science and Nutrition 38, 421-464.

Cishek MB, Galloway MT, Karim M, German JB \& Kappagoda CT (1997) Effect of red wine on endothelium-dependent relaxation in rabbits. Clinical Science $\mathbf{9 3}, 507-511$.

Cook NC \& Samman S (1996) Flavonoids - chemistry, metabolism, cardioprotective effects and dietary sources. Nutritional Biochemistry 7, 66-76.

Crique MH \& Ringel BL (1994) Does diet or alcohol explain the French paradox? Lancet 344, 1719-1723.

Cromheeke KM, Kockx MM, DeMeyer GRY, Bosmans JM, Bul TH, Beelaerts WJ, Vrints CJ \& Herman AG (1999) Inducible nitric oxide synthase colocalizes with signs of lipid oxidation/peroxidation in human atherosclerotic plaques. Cardiology Research 43, 744-754.

Cuevas AM, Guasch V, Castillo O, Irribarra V, Mizon C, San Martin A, Strobel P, Perez D, Germain AM \& Leighton F (2000) A high-fat diet induces and red wine counteracts endothelial dysfunction in human volunteers. Lipids $\mathbf{3 5}$, 143-148.

Day AJ, Bao Y, Morgan MRA \& Williamson G (2000) Conjugation position of quercetin glucuronides and effect on biological activity. Free Radical Biology and Medicine 29, 1234-1243.

Day AMP, Kemp HJ, Bolton C, Hertog M \& Stansbie D (1997) Effect of concentrated red grape juice consumption on serum antioxidant capacity and low density lipoprotein oxidation. Annals of Nutrition and Metabolism 41, 353-357.

Deckert V, Desrumaux C, Athias A, Duverneuil L, Palleau V, Gambert P, Masson D \& Lagrost L (2002) Prevention of LDL [alpha]-tocopherol consumption, cholesterol oxidation, and vascular endothelium dysfunction by polyphenolic compounds from red wine. Atherosclerosis 165, 41-50.

Demrow HS, Slane PR \& Folts JD (1995) Administration of wine and grape juice inhibits in vivo platelet activity and thrombosis in stenosed canine coronary arteries. Circulation 91, 1182-1188.

de Pascual-Teresa S, Rivas-Gonzalo JC \& Santos-Buelga C (2000) Prodelphinidins and related flavanols in wine. International Journal of Food Sciences and Nutrition 35, 33-40.

de Rijke YB, Demacker PNM, Assen NA, Sloots LM, Katan MB \& Stalenhoef AFH (1996) Red wine consumption does not affect oxidisability of low density lipoproteins in volunteers. American Journal of Clinical Nutrition 63, 329-334.

Di Bari M, Zacchei S, Kritchevsky SB, Anichini M, Cesaretti S, Chiarlone M, Masotti G \& Marchionni N (2003) Anti-oxidized LDL antibodies and wine consumption: a population-based epidemiological study in Dicomano, Italy. Annals of Epidemiology 13, 189-195.

Ector BJ, Magee JB, Hegwood CP \& Coign MJ (1996) Resveratrol concentration in muscadine berries, juice, pomace, purees, seeds and wines. American Journal of Enology and Viticulture 47, 57-62.

Estruch R (2000) Wine and cardiovascular disease. Food Research International 33, 219-226.

Francia-Aricha EM, Gerra MT, Rivas-Gonzalo JC \& SantosBuelga C (1997) New anthocyanin pigments formed after condensation with flavanols. Journal of Agricultural and Food Chemistry 45, 2262-2266.

Frankel EN, Kanner J, German JB, Parks E \& Kinsella JE (1993) Inhibition of oxidation of human low-density lipoprotein by phenolic substances in red wine. Lancet 341, 454-457.

Fuhrman B, Lavy A \& Aviram M (1995) Consumption of red wine with meals reduces the susceptibility of human plasma and low density lipoprotein to lipid peroxidation. American Journal of Clinical Nutrition 61, 549-554.

Goldberg DM, Garovic-Kocic V, Diamandis EP \& Pace-Asciak CR (1996) Wine: does the colour count? Clinica Chimica Acta 246, 183-193.

Goldberg DM, Hahn SE \& Parkes JG (1995a) Beyond alcohol: beverage consumption and cardiovascular mortality. Clinica Chimica Acta 237, 155-187.

Goldberg DM, Karumanchiri A, Tsang E \& Soleas GL (1998) Catechin and epicatechin concentrations of red wines: regional and cultivar-related differences. American Journal of Enology and Viticulture 49, 23-34.

Goldberg DM, Yan J, Ng E, Diamandis EP, Karumanchiri A, Soleas GL \& Waterhouse AL (1995b) A global survey of transresveratrol concentrations in commercial wines. American Journal of Enology and Viticulture 46, 159-165.

Graham A, Hogg N, Kalyanaraman B, O’Leary V, Darley-Usmar V \& Moncada S (1993) Peroxynitrite modification of low-density lipoprotein leads to recognition by the macrophage scavenger receptor. FEBS Letters 330, 181-185.

Han J, Hajjar DP, Tauras JM \& Nicholson AC (1999) Cellular cholesterol regulates expression of the macrophage type B scavenger receptor, CD36. Journal of Lipid Research 40, 830-838.

Harbourne J (1994) The Flavonoids: Advances in Research Since 1986. London: Chapman \& Hall.

Harbourne J (2000) Chemistry of the flavonoid pigments. In Wake up to Flavonoids, pp.3-12 [C Rice-Evans, editor]. London: Royal Society of Medicine Press Ltd.

Harbourne J \& Williams C (2000) Advances in flavonoid research since 1992. Phytochemistry 55, 481-504.

Hayek T, Fuhrman B, Vaya J, Rosenblat M, Belinky P, Coleman R, Elis A \& Aviram M (1997) Reduced progression of atherosclerosis in apolipoprotein E-deficient mice following consumption of red wine, or its polyphenols quercetin or catechin, is associated with reduced susceptibility of LDL to oxidation and aggregation. Arteriosclerosis, Thrombosis, and Vascular Biology 17, 2744-2752.

Hazen SL, Zhang R, Shen Z, Wu W, Podrez EA, MacPherson JC, Schmitt D, Mitra SN, Mukhopadhyay C, Chen Y, Cohen PA, Hoff HF \& Abu-Soud HM (1999) Formation of nitric oxidederived oxidants by myeloperoxidase in monocytes. Pathways for monocyte-mediated protein nitration and lipid peroxidation in vivo. Circulation Research 85, 950-958.

Hertog MGL, Hollman PCH \& van de Putte B (1993) Content of potentially anti-carcinogenic flavonoids of tea infusions, wines and fruit juices. Journal of Agricultural and Food Chemistry 41, 1242-1246.

Hollman PCH (1997) Bioavailability of flavonoids. European Journal of Clinical Nutrition 51, S66-S69.

Hollman PCH \& Arts ICW (2000) Flavonols, flavones and flavanols - nature, occurrence and dietary burden. Journal of the Science of Food and Agriculture 80, 1081-1093.

Husain SR, Cillard J \& Cillard P (1987) Hydroxyl radical scavenging activity of flavonoids. Phytochemistry 26, 2489-2491. 
Iijima K, Yoshizumi M, Hashimoto M, Kim S, Eto M, Ako J, Liang Y-Q, Sudoh N, Hosoda K, Nakahara K, Toba K \& Ouchi Y (2000) Red wine polyphenols inhibit proliferation of vascular smooth muscle cells and downregulate expression of Cyclin A gene. Circulation 101, 805-811.

Iijima K, Yoshizumi M \& Ouchi Y (2002) Effect of red wine polyphenols on vascular smooth muscle cell function - molecular mechanism of the 'French paradox'. Mechanisms of Ageing and Development 123, 1033-1039.

Jackson RS (1994) Wine Science: Principles and Applications. London: Academic Press, Inc.

Janssen PLTMK, Katan MB, Hollman PCH \& Venema DP (1994) No aspirin in red wine. Lancet 344, 762.

Janssen PLTMK, Mensink RP, Cox FJJ, Harryvan JL, Hovenier R, Hollman PCH \& Katan MB (1998) Effects of the flavonoids quercetin and apigenin on hemostasis in healthy volunteers: results from an in vitro and a dietary supplement study. American Journal of Clinical Nutrition 67, 255-262.

Jeandet P, Bessis R, Maume BF \& Sbaghi M (1993) Analysis of resveratrol in burgundy wines. Journal of Wine Research 4, 79-85.

Jeandet P, Bessis R, Sbaghi M, Meunier P \& Trollat P (1995) Resveratrol content of wines of different ages: relationship with fungal disease pressure in the vineyard. American Journal of Enology and Viticulture 46, 1-4.

Klurfeld DM \& Kritchevsky D (1981) Differential effects of alcoholic beverages on experimental atherosclerosis in rabbits. Experimental Molecular Pathology 34, 62-71.

Koga T \& Meydani M (2001) Effect of plasma metabolites of (+)catechin and quercetin on monocyte adhesion to human aortic endothelial cells. American Journal of Clinical Nutrition 73, 941-948.

Kondo K, Matsumoto A, Kurata H, Tanahashi H, Koda H, Amachi T \& Itakura H (1994) Inhibition of oxidation of low density lipoprotein with red wine. Lancet 344, 1152.

Kushi LH, Lenart EB \& Willett WC (1995) Health implications of Mediterranean diets in light of contemporary knowledge. 2. Meat, wine, fats and oils. American Journal of Clinical Nutrition 61, 1416S-1427S.

Lamuela-Raventós RM, Romero-Pérez AI, Waterhouse AL \& de la Torre-Boronat MC (1995) Direct HPLC analysis of cis- and trans-resveratrol and piceid isomers in Spanish red Vitis vinifera wines. Journal of Agricultural and Food Chemistry 43, 281-283.

Lamuela-Raventós RM \& Waterhouse AL (1993) Occurrence of resveratrol in selected Californian wines by a new HPLC method. Journal of Agriculture and Food Chemistry 41, 521-523.

Landolfi R, Mower RL \& Steiner M (1984) Modification of platelet function and arachidonic acid metabolism by bioflavonoids. Biochemical Pharmacology 33, 1525-1530.

Lanningham-Foster L, Chen C, Chance DS \& Loo G (1995) Grape extract inhibits lipid peroxidation of human LDL. Biological and Pharmaceutical Bulletin 18, 1347-1351.

Lavy A, Fuhrman B, Markel A, Dankner G, Ben-Amotz A, Presser D \& Aviram M (1994) Effect of dietary supplementation of red or white wine on human blood chemistry, haematology and coagulation: favourable effect of red wine on plasma high-density lipoprotein. Annals of Nutrition and Metabolism 38, 287-294.

Law M \& Wald N (1999) Why heart disease mortality is low in France: the time lag explanation. British Medical Journal 318, 1471-1480.

Li TK, Yin SJ, Crabb DW, O'Connor S \& Ramchandani VA (2001) Genetic and environmental influences on alcohol metabolism in humans. Alcoholism, Clinical and Experimental Research 21, 136-144.

Liu XQ, Buchanan W, Mathews AJ, Chung BH \& Bagdale JD (1997) Lack of effect of vitamin E on cholesterol ester transfer and lipoprotein composition on cholesterol fed rabbits. Comparative Biochemistry and Physiology 117B, 553-559.

Liu Y \& Liu G (2004) Isorhaptontigenin and resveratrol suppress oxLDL-induced proliferation and activation of ERK1/2 mitogen-activated protein kinases of bovine aortic smooth muscle cells. Biochemical Pharmacology 15, 777-785.

McCaffrey TA (2000) TGF- $\beta$ s and TGF- $\beta$ receptors in atherosclerosis. Cytokine and Growth Factor Reviews 11, 103-114.

McElduff P \& Dobson AJ (1997) How much alcohol and how often? Population based case-control study of alcohol consumption and risk of a major coronary event. British Medical Journal 314, 1159-1164.

Mangiapane EH \& Salter A (1999) Diet, Lipoproteins and Coronary Heart Disease. A Biochemical Perspective. Nottingham: Nottingham University Press.

Martens JS, Lougheed M, Gomez-Munoz A \& Steinbrecher UP (1999) A modification of apolipoprotein B accounts for most of induction of macrophage growth by oxidised low-density lipoprotein. Journal of Biological Chemistry 274, 10903-10910.

Maziere C, Alimardani G, Dantin F, Conte MA \& Maziere JC (1999) Oxidised LDL activates signal transducers and activators of transcription 1 and signal transducers and activators of transcription 3 transcription factors: possible involvement of reactive oxygen species. FEBS Letters 448, 49-52.

Middleton E \& Kandaswami C (1995) The impact of plant flavonoids on mammalian biology: implications for immunity, inflammation and cancer. In The Flavonoids: Advances in Research Since 1986, pp.619-652 [J Harbourne, editor]. London: Chapman \& Hall.

Nestle M (1995) Mediterranean diets: historical and research overview. American Journal of Clinical Nutrition 61 , 1313S-1320S.

Nigdikar SV \& Howard AN (1997a) Antioxidant activity of red wine polyphenols in vivo. Atherosclerosis 134, 203 Abstr.

Nigdikar SV \& Howard AN (1997b) Red wine polyphenols increase plasma total TGF- $\beta$. Atherosclerosis 1-2, 275 Abstr.

Nigdikar SV, Williams NR, Griffin BA \& Howard AN (1998) Consumption of red wine polyphenols reduces the susceptibility of low-density lipoproteins to oxidation in vivo. American Journal of Clinical Nutrition 68, 258-265.

Okuda T \& Yokotsuma K (1996) Trans-resveratrol concentrations in berry skins and wines from grapes grown in Japan. American Journal of Enology and Viticulture 47, 93-99.

Pace-Asciak CR, Rounova O, Hahn SE, Diamandis EP \& Goldberg DM (1996) Wines and grape juices as modulators of platelet aggregation in healthy human subjects. Clinica Chimica Acta 246, 163-182.

Parhami F, Fang ZT, Fogelman AM, Andalibi A, Territo MC \& Berliner JA (1993) Minimally modified low density lipoproteininduced inflammatory responses in endothelial cells are mediated by cyclic adenosine monophosphate. Journal of Clinical Investigation 92, 471-478.

Parr AJ \& Bolwell GP (2000) Phenols in the plant and in man. The potential for possible nutritional enhancement of the diet by modifying the phenols content or profile. Journal of the Science of Food and Agriculture 80, 985-1012.

Pezet R, Pont V \& Cuenet P (1994) Method to determine resveratrol and pterostilbene in grape berries and wines using highperformance liquid chromatography and highly sensitive fluorimetric detection. Journal of Chromatography 663A, 191-197.

Pignatelli P, Pulcinelli FM, Celestini A, Lenti L, Ghiselli A, Gazzaniga PP \& Violi F (2000) The flavonoids quercetin and catechin synergistically inhibit platelet function by antagonising the intracellular production of hydrogen peroxide. American Journal of Clinical Nutrition 72, 1150-1155.

Plumb GW, de Pascual-Teresa S, Santos-Buelga C, Cheynier V \& Williamson G (2000) Antioxidant properties of catechins and 
proanthocyanidins: effect of polymerisation, galloylation and glycosylation. Free Radical Biology and Medicine 29, 351-358.

Podrez EA, Schmitt D, Hoff HF \& Hazen SL (1999) Myelopreoxidase-generated reactive nitrogen species convert LDL into an atherogenic form in vitro. Journal of Clinical Investigation 103, 1547-1560.

Prasad K \& Kalra J (1993) Oxygen free radicals and hypercholesterolaemic atherosclerosis - effect of vitamin E. American Heart Journal 125, 958-973.

Renaud S, Beswick AD, Fehily AM, Sharp DS \& Elwood PC (1992) Alcohol and platelet aggregation: the Caerphilly Prospective Heart Disease Study. American Journal of Clinical Nutrition 55, 1012-1017.

Renaud S \& de Lorgeril M (1992) Wine, alcohol, platelets, and the French paradox for coronary heart disease. Lancet 339, 1523-1526.

Rendig SV, Symons D, Longhurst JC \& Amsterdam EA (2000) Effects of red wine, alcohol, and the red wine flavonoid, quercetin, on isolated coronary resistance and conductance arteries. Journal of the American College of Cardiology 35, 245A.

Rice-Evans C \& Miller NJ (1996) Antioxidant activities of flavonoids as bioactive components of food. Biochemical Society Transactions 24, 790-795.

Rifici VA, Stephan EM, Schneider SH \& Khachadurian AK (1999) Red wine inhibits the cell-mediated oxidation of LDL and HDL. Journal of the American College of Nutrition 18, 137-143.

Rimm EB, Klatsky AL, Grobbee D \& Stampfer MJ (1996) Review of moderate alcohol consumption and reduced risk of coronary heart disease: is the effect due to beer, wine, or spirits? British Medical Journal 312, 731.

Ruf JC, Berger JL \& Renaud S (1995) Platelet rebound effect of alcohol withdrawal and wine drinking in rats. Arteriosclerosis, Thrombosis and Vascular Biology 15, 140-144.

Santos-Buelga C \& Scalbert A (2000) Proanthocyanidins and tannin-like compounds - nature, occurrence, dietary intake and effects on nutrition and health. Journal of the Science of Food and Agriculture 80, 1094-1117.

Saucier C, Guerra C, Pianet I, Laguerre M \& Glories Y (1997) (+)-Catechin-acetaldehyde condensation products in relation to wine-ageing. Phytochemistry 46, 229-234.

Seigneur M, Bonnet J, Dorian B, Benchimol D, Drouillet F, Gouverneur G, Larrue J, Crockett R, Boisseau M-R, RibereauGayon P \& Bricaud H (1990) Effect of the consumption of alcohol, white wine and red wine on platelet function and serum lipids. Journal of Applied Cardiology 5, 215-222.

Serafini M, Maiani G \& Ferro-Luzzi A (1998) Alcohol-free red wine enhances plasma antioxidant capacity in humans. Journal of Nutrition 128, 1003-1007.

Sharpe PC, McGrath LT, McClean E, Young IS \& Archbold GPR (1995) Effect of red wine consumption on lipoprotein (a) and other risk factors for atherosclerosis. Quarterly Journal of Medicine 88, 101-108.

Shen GX, Noval C \& Angel A (1996) Effect of dietary vitamin E supplementation on cholesterol ester transfer activity in hamster adipose tissue. Atherosclerosis 124, 211-219.

Shimoi K, Saka N, Kaji K, Nozawa R \& Kinae N (2000) Metabolic fate of luteolin and its functional activity at focal site. Biofactors 12, 181-186.

Singh GK \& Hoyert DL (2000) Social epidemiology of chronic liver disease and cirrhosis mortality in the United States, 1935-1997: trends and differentials by ethnicity, socioeconomic status, and alcohol consumption. Human Biology 72, 801-820.

Singleton VL (1982) Grape and wine phenolics; background and prospects. In Grape and Wine Centennial Symposium, Proceedings of the University of California, Davis, pp. 215-227 [AD Webb, editor]. Davis, CA: University of California Press.

Singleton VL \& Rossi JA (1965) Colorimetry of total phenolics with phosphomolybdic-phosphotungstic acid reagents. American Journal of Enology and Viticulture 16, 144-158.
Soleas GL, Diamandis EP \& Goldberg DM (1997a) Wine as a biological fluid: history, production, and role in disease prevention. Journal of Clinical Laboratory Analysis 11, 287-313.

Soleas GL, Goldberg DM, Diamandis EP, Karumanchiri A, Yan J $\& \mathrm{Ng}$ E (1995) A derivatised gas chromatographic-mass spectrometric method for the analysis of both isomers of resveratrol in juice and wine. American Journal of Enology and Viticulture 46, 346-352.

Soleas GL, Tomlinson G, Diamandis EP \& Goldberg DM (1997b) Relative contributions of polyphenolic constituents to the antioxidant status of wines: development of a predictive model. Journal of Agricultural and Food Chemistry 45, 3995-4003.

St Leger AS, Cochrane AL \& Moore F (1979) Factors associated with cardiac mortality in developed countries with particular reference to the consumption of wine. Lancet i, 1017-1020.

Sugiyama A, Saitoh M, Takahara A, Satoh Y \& Hashimoto K (2003) Acute cardiovascular effects of a new beverage made of wine vinegar and grape juice, assessed using an in vivo rat. Nutrition Research 23, 1291-1296.

Sun GY, Xia J, Xu J, Allenbrand B, Simonyi A, Rudeen PK \& Sun AY (1999) Dietary supplementation of grape polyphenols to rats ameliorates chronic ethanol-induced changes in hepatic morphology without altering changes in hepatic liquids. Journal of Nutrition 129, 1814-1819.

Suzuki A, Kagawa D, Fujii A, Ochiai R, Tokimitsu I \& Saito I (2002) Short- and long-term effects of ferulic acid on blood pressure in spontaneously hypertensive rats. American Journal of Hypertension 15, 351-357.

Tedesco I, Russo M, Russo P, Iacomino G, Russo GL, Carraturo A, Faruolo C, Moio L \& Palumbo R (2000) Antioxidant effect of red wine polyphenols on red blood cells. Journal of Nutritional Biochemistry 11, 114-119.

Teissedre P-L, Frankel EN, Waterhouse AL, Peleg H \& German JB (1996) Inhibition of in vitro LDL oxidation by phenolic antioxidants from grapes and wines. Journal of the Science of Food and Agriculture 70, 55-61.

The Wine Institute (1999) Per capita wine consumption by country in liters and gallons per capita. www.wineinstitute.org

Thurnham DI, Davies JA, Crump BJ, Situnayake RD \& Davis M (1986) The use of different lipids to express serum tocopherol:lipid ratios for the measurement of vitamin E status. Annals of Clinical Biochemistry 23, 514-520.

Tjønneland A, Grønbæk M, Stripp C \& Overvad K (1999) Wine intake and diet in a random sample of 48,763 Danish men and women. American Journal of Clinical Nutrition 69, 49-54.

Trichopoulou A, Kouris-Blazos A, Vassilakou T, Gnardellis C, Polychronopoulos E, Venizelos M, Lagiou P, Wahlqvist ML \& Trichopoulos D (1995) Diet and survival of elderly Greeks: a link to the past. American Journal of Clinical Nutrition 61 , 1346S-1350S.

Tsimikas S, Palinski W \& Witztum JL (2001) Circulating autoantibodies to oxidised LDL correlate with arterial accumulation and depletion of oxidised LDL in LDL receptor-deficient mice. Arteriosclerosis, Thrombosis, and Vascular Biology 21, 95-100.

UK Trade and Investment (2004) Food and Drink Market in France. www.uktradeinvest.gov.uk/food/france/profile/ overview.shtml

Ursini F, Tubaro F, Rong J \& Sevanian A (1999) Optimisation of nutrition: polyphenols and vascular protection. Nutrition Reviews 57, 241-249.

van Der Gaag MS, van Tol A, Vermunt SH, Scheek LM, Schaafsma G \& Hendriks HFJ (2001) Alcohol consumption stimulates early steps in reverse cholesterol transport. Journal of Lipid Research 42, 2077-2083.

Viana M, Barbas C, Bonet B, Bonet MV, Castro M, Fraile V \& Herrera E (1996) In vitro effects of a flavonoid-rich extract on LDL oxidation. Atherosclerosis 123, 83-91. 
Vinson JA, Teufel K \& Wu N (2001) Red wine, dealcoholized red wine, and especially grape juice, inhibit atherosclerosis in a hamster model. Atherosclerosis 156, 67-72.

Virgili F, Kobuchi H \& Packer L (1998) Nitrogen monoxide (NO) metabolism: antioxidant properties and modulation of inducible NO synthase activity in activated macrophages by procyanidins extracted from Pinus maritima (Pycnogenol®). In Flavonoids in Health and Disease, pp.421-436 [C Rice-Evans and L Packer, editors]. New York: Marcel Dekker, Inc.

Vogel RA (2003) Vintners and vasodilators: are French red wines more cardioprotective? Journal of the American College of Cardiology 41, 479-481.

Von Wartburg J-P, Buhler R, Maring J-A \& Pestalozzi D (1983) The polymorphisms of alcohol and aldehyde dehydrogenase and their significance for acetaldehyde toxicity. Pharmacology Biochemistry and Behavior 18, 123-125.

Wallerath T, Poleo D, Li H \& Forstermann U (2003) Red wine increases the expression of human endothelial nitric oxide synthase: a mechanism that may contribute to its beneficial cardiovascular effects. Journal of the American College of Cardiology 41, 471-478.

Waterhouse AL \& Walzem RL (1998) Nutrition of grape phenolics. In Flavonoids in Health and Disease, pp.359-385 [C RiceEvans and L Packer, editors]. New York: Marcel Dekker, Inc.

Whitehead TP, Robinson D, Allaway S, Syms J \& Hale A (1995)
Effect of red wine ingestion on the antioxidant capacity of serum. Clinical Chemistry 41, 32-35.

Willett WC, Sacks F, Trichopoulou A, Drescher G, Ferro-Luzzi A, Helsing E \& Trichopoulos D (1995) Mediterranean diet pyramid: a cultural model for healthy eating. American Journal of Clinical Nutrition 61, 1402S-1406S.

Wippel R, Rehn M, Gorren ACF, Schmidt K \& Mayer B (2004) Interference of the polyphenol epicatechin with the biological chemistry of nitric oxide- and peroxynitrite-mediated reactions. Biochemical Pharmacology 67, 1285-1295.

Witztum JL \& Steinberg D (2001) The oxidative modification hypothesis of atherosclerosis: does it hold for humans? Trends in Cardiovascular Medicine 11, 93-102.

World Health Organization (1989) The WHO MONICA Project. A worldwide monitoring system for cardiovascular diseases: cardiovascular mortality and risk factors in selected communities. In World Health Statistics A, pp. 27-149. Geneva: WHO.

Zhang Q-H, Das K, Siddiqui S \& Myers AK (2000) Effects of acute, moderate ethanol consumption on human platelet aggregation in platelet-rich plasma and whole blood. Alcoholism, Clinical and Experimental Research 24, 528-534.

Zhu Q-Y, Huang Y \& Chen Z-Y (2000) Interaction between flavonoids and $\alpha$-tocopherol in human low density lipoprotein. Journal of Nutritional Biochemistry 11, 14-21. 


\title{
Are you a Registered Nutritionist?
}

\author{
The Nutrition Society
}

The Society's registers form part of a scheme to protect the public. The registers help to set and promote high standards of education and professional development in nutrition. The register helps employers, the media and the general public to identify appropriately qualified individuals. Members on the register are expected to adhere to the Society's Code of Ethics and the Statement of Professional Conduct. Since 2000 the status and size of the scheme has risen. Increasing numbers of employers, partner professional bodies and government departments in Britain recognise registration with the Society as a sign of quality. Members, employers and the general public can find a registered nutritionist on the Society's register at www.nutritionsociety.org/membership/register.

\section{Register of Nutritionists}

Members of the Nutrition Society can apply for Registration in Nutrition, the use of the title Registered Nutritionist and the letters $R$ Nutr after their name. Members of the Society who have been working in the field of nutrition for a minimum of three years and who have academic qualifications in nutrition, dietetics or a related subject are eligible to apply. Until 2007, other relevant qualifications may also be acceptable. Accredited Nutritionists can apply to transfer to the Society's register.

\section{Associate registration in Nutrition}

Members with an acceptable degree in nutrition or a bioscience with a major in nutrition may apply for registration as Associate Nutritionists. This confers the title Associate Nutritionist and letters A Nutr.

\section{Register of Public Health Nutritionists}

The first specialist category of the Register is the Register for Public Health Nutritionists. Members of the Society who have been working in the field of Public Health Nutrition for a minimum of three years in the last five and who have appropriate qualifications are eligible to apply. Members who fulfil the criteria for registration are able to use the title Public Health Nutritionist and the letters RPHNutr after their name.

\section{Associate registration in Public Health Nutrition}

Only members who graduated from one of the seven courses accredited by the Society are eligible for registration as Associate Public Health Nutritionists. This confers the title Associate Public Health Nutritionist and letters APHNutr.

Apply by sending

- A recent CV,

- Certified copy of qualification certificate(s) with transcripts.

- Names of THREE academic and/ or professional references

- A statement of competence

- Completed registration application form (from the website)

- The appropriate fee (see website).

Fees

The Society welcomes all applications. However, in 2004 individuals educated and resident outside the European Union will pay higher fees a reflection of the higher administration costs. Annual retention fees will not change. Registrants who lapse may be asked to pay a reinstatement fee.

For a copy of a detailed guide or information about the Registers, registration fees and about the Accreditation of Courses in Public Health Nutrition contact:

The Registrar,

The Nutrition Society,

10 Cambridge Court, 210 Shepherds Bush Rd, London W6 7NJ, ENGLAND Fax +44 (0) 207602 1756; Email: office@nutsoc.org.uk.

More details and news about developments can be found on the Society's Website: www.nutritionsociety.org.uk 